Original Article

\title{
Photosynthetic acclamatory response of Panicum antidotale Retz. populations to root zone desiccation stress
}

\author{
Reação fotossintética aclamatória de Panicum antidotale Retz. populações submetidas \\ ao estresse da dessecação da zona radicular
}

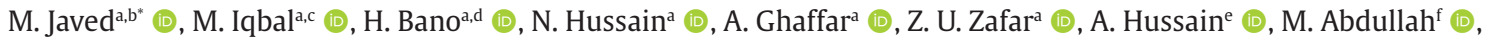

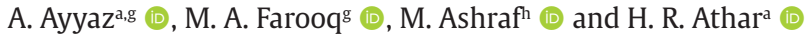 \\ aBahauddin Zakariya University, Institute of Pure and Applied Biology, Multan, Pakistan \\ bUniversity of Education, Department of Botany, Division of Science and Technology, Lahore, Pakistan \\ 'University of Okara, Department of Botany, Okara, Pakistan \\ dThe Women University Multan, Department of Botany, Multan, Pakistan \\ ${ }^{\mathrm{e}}$ Cotton Research Institute, Multan, Pakistan \\ 'The Islamia University of Bahawalpur, Cholistan Institute of Desert Studies, Bahawalpur, Pakistan \\ 'Zhejiang University, College of Agriculture and Biotechnology, Zijingang Campus, Hanzhou, China \\ hUniversity of Agriculture, Faisalabad, Pakistan
}

\begin{abstract}
Growth of plants is severely reduced due to water stress by affecting photosynthesis including photosystem II (PSII) activity and electron transport. This study emphasised on comparative and priority targeted changes in PSII activity due to progressive drought in seven populations of Panicum antidotale (P. antidotale) collected from Cholistan Desert and non-Cholistan regions. Tillers of equal growth of seven populations of $P$. antidotale grown in plastic pots filled with soil were subjected progressive drought by withholding water irrigation for three weeks. Progressive drought reduced the soil moisture content, leaf relative water content, photosynthetic pigments and fresh and dry biomass of shoots in all seven populations. Populations from Dingarh Fort, Dingarh Grassland and Haiderwali had higher growth than those of other populations. Cholistani populations especially in Dingarh Grassland and Haiderwali had greater ability of osmotic adjustment as reflected by osmotic potential and greater accumulation of total soluble proteins. Maximum $\mathrm{H}_{2} \mathrm{O}_{2}$ under water stress was observed in populations from Muzaffargarh and Khanewal but these were intermediate in MDA content. Under water stress, populations from Muzaffargarh and Dingarh Fort had greater $\mathrm{K}^{+}$accumulation in their leaves. During progressive drought, nonCholistani populations showed complete leaf rolling after 23 days of drought, and these populations could not withstand with more water stress condition while Cholistani populations tolerated more water stress condition for 31 days. Moreover, progressive drought caused PSII damages after 19 days and it became severe after 23 days in non-Cholistani populations of $P$. antidotale than in Cholistani populations.
\end{abstract}

Keywords: grasses, relative water content, osmotic adjustment, photosystem-II, OJIP.

\begin{abstract}
Resumo
O crescimento das plantas é severamente reduzido devido ao estresse hídrico, afetando a fotossíntese, incluindo a atividade do fotossistema II (PSII) e o transporte de elétrons. Este estudo enfatizou as mudanças comparativas e prioritárias na atividade do PSII devido à seca progressiva em sete populações de Panicum antidotale (P. antidotale) coletadas no Deserto do Cholistão e regiões fora do Cholistão. Perfilhos de igual crescimento de sete populações de $P$. antidotale cultivadas em vasos de plástico cheios de solo foram submetidos à seca progressiva, retendo a irrigação com água por três semanas. A seca progressiva reduziu o teor de umidade do solo, teor de água relativo nas folhas, pigmentos fotossintéticos e biomassa fresca e seca dos brotos em todas as sete populações. Populações de Dingarh Fort, Dingarh Grassland e Haiderwali tiveram maior crescimento do que as de outras populações. As populações de Cholistani, especialmente em Dingarh Grassland e Haiderwali, apresentaram maior capacidade de ajuste osmótico, refletido pelo potencial osmótico e maior acúmulo de proteínas solúveis totais. $\mathrm{H}_{2} \mathrm{O}_{2}$ máximo sob estresse hídrico foi observado em populações de Muzaffargarh e Khanewal, mas estas foram intermediárias no conteúdo de MDA. Sob estresse hídrico, as populações de Muzaffargarh e Dingarh Fort tiveram maior acúmulo de $\mathrm{K}^{+}$em suas folhas. Durante a seca progressiva, as populações não cholistanesas mostraram rolagem completa das folhas após 23 dias de seca, e essas populações não conseguiram suportar mais condições de estresse hídrico, enquanto as populações cholistani toleraram mais condições de estresse hídrico por 31 dias. Além disso, a seca progressiva causou danos ao PSII após 19 dias e tornou-se severa após 23 dias em populações não cholistanesas de $P$. antidotale do que em populações cholistanesas.
\end{abstract}

Palavras-chave: gramíneas, conteúdo relativo de água, ajuste osmótico, fotossistema II, OJIP.

*e-mail: javedbotany@gmail.com

Received: May 28, 2021 - Accepted: September 21, 2021

This is an Open Access article distributed under the terms of the Creative Commons Attribution License, which permits unrestricted use, distribution, and reproduction in any medium, provided the original work is properly cited. 


\section{Introduction}

Water stress is a potential threat to plant growth and productivity losses. These losses may reach up to 50\% subject to severity of water stress (Wang et al., 2003). It is compulsory for plant to maintain $80-90 \%$ water content to carryout metabolic and physiological processes such as cell division and cell enlargement, $\mathrm{CO}_{2}$ fixation into carbohydrates, nitrogen metabolism etc. (Lawlor and Cornic, 2002). Plants loose cell turgor when experience water deficit conditions because of lower uptake of water through roots or greater rate of water transpiration under water stress conditions. Water stress decreased water and nutrient uptake in plants due to decreased membrane permeability, active transport and transpiration (Du et al., 2010). Drought stress decreased soil water content, limiting water and nutrient uptake thus causing osmotic stress and oxidative stress in different cellular parts of plant cells (Blum, 2017). To avoid osmotic stress, plants accumulate various inorganic and organic osmolytes which lower the plant water potential and cell osmotic potential that result in osmotic adjustment (Zlatev et al., 2006; Taiz et al., 2015).

In natural water deficit conditions, selection pressure selects plants with reduced leaf area. Plants with smaller leaves or small leaf area were better able to maintain plant water status by lowering transpiration rate and thus save soil water for later but more important reproductive stage (Boyer, 1982). To reduce transpirational water loss reducing leaf area is better strategy than stomatal closure, where leaf temperature is substantially increased (Guilioni et al., 2008). Researchers are struggling to uncover plant water saving strategies or water use efficient mechanism which can be used to enhance water stress tolerance in plants (Blum, 2005).

Photosynthesis is known to be disturbed by mild to severe drought stress and affects plant growth (Ashraf and Harris, 2013). Photosynthesis is generally limited by abiotic stresses including drought or water stress either through stomatal limitation or metabolic limitation (Guan et al., 2015). Drought also affects thylakoidal reactions to produce ATPs by limiting electron transport. Imbalance in production and consumption in reducing equivalents through electron transport leads to reactive oxygen species (ROS) formation and causes photoinhibition or photodamage of PSII. Chlorophyll fluorescence is an important non-intrusive method to assess health status of photosynthetic apparatus. Moreover, it can be used for discriminating species or populations of same species for their tolerance against abiotic stresses including drought (Ashraf and Harris, 2013; Goltsev et al., 2016; Ruban, 2016; Kirst et al., 2017; Murchie, 2017). For example, chlorophyll fluorescence was reported to be an effective indicator of drought tolerance in several plant species, e.g., mulberry (Guha et al., 2013).

Although ROS are mainly produced in chloroplast, these are also generated in mitochondria and peroxisomes (Apel and Hirt, 2004). In plants, several antioxidant enzymes and antioxidant compounds effectively scavenge ROS species to protect cellular organelles under normal or stress conditions (Ashraf, 2009). Several studies reported that drought tolerance is correlated with greater antioxidant potential
(Gossett et al., 1994). It is also suggested that plants ability to reduce ROS generation or oxidative damage by regulating electron transport were higher tolerant to drought stress than those having greater antioxidant potential but lower capability in regulating electron transport. This argument is supported by the fact that investment of metabolic energy in enhanced production of antioxidants enzymes is greater than in regulating electron transport.

Deserts are primarily characterized by drought and high temperature stress. In Cholistan desert, annual rain fall is low and naturally occurring water bodies on permanent basis are totally absent (Arshad et al., 2008). Its vegetation consists of grasses, herbs, shrubs and trees. Vegetation of Cholistan desert are major source of food for livestock (Arshad et al., 2008).

Of various grass species, $P$. antidotale is dominant, highly frequent and nutritive grass species having high ecological amplitude, thus found growing on normal and drought hit lands (Hameed et al., 2002; Naz et al., 2009). Different $P$. antidotale populations growing on drought-hit areas of Cholistan desert or on normal soil might have experience of degree of water stress for a long time. Presence of specific genomic differences and specific selection pressure are two key factors responsible for development of specific physiological trait for stress tolerance (Noble et al., 1984; Ashraf et al., 1986; Ashraf and McNeilly, 1990; Al-Khatib et al., 1992). Thus it is possible that some of drought tolerance traits have been fixed in some populations of $P$. antidotale growing on drought hit areas and these populations may vary considerably in terms of water stress tolerance. It is also possible that $P$. antidotale populations may also differ in the regulation of drought tolerance mechanisms. Thus, the primary objective was to assess physiological basis of tolerance to drought stress in $P$. antidotale populations differing in degree of drought tolerance by assessing physiological and biochemical characters.

\section{Materials and Methods}

Tillers of $P$. antidotale were collected from natural population at different sites across the districts Muzaffargarh, Multan, Khanewal and Bahawalpur. Twenty mature plants of each population were collected and identified and verified by Prof. Dr. Zafar Ullah Zafar, Institute of Pure and Applied Biology, Bahauddin Zakariya University, Multan. Stumps of all plants were thereafter grown in pots filled with garden soil in a wire net house at the Botanic Gardens of Bahauddin Zakariya University, Multan Pakistan. The plants were kept under full sunlight and irrigated daily till their establishment.

The experiment was organised in a completely randomized design (CRD) having two factors (population and drought level) and four replicates. Randomly selected four tillers from each population of equal size for each replication were detached and transplanted in pots filled with garden soil. Pots had drainage holes at bottom and plants were irrigated regularly with tap water. After establishment, plants were pruned to make them uniform in size. Two drought levels were maintained i-e control 
(regular irrigation) and drought (irrigation at soil saturation level then no irrigation). After three weeks of drought stress, plants were harvested. Before harvesting plants, photosynthetic pigments, relative water content, soil moisture content, osmotic potential, total soluble proteins, total free amino acids, hydrogen peroxide, malondialdehyde, potassium accumulation and fast chlorophyll $a$ kinetic analysis were measured.

\subsection{Biomass}

Plants were harvested from the pots after the completion of experiment. During harvesting roots were removed carefully and plants were cut into roots and shoots for the purpose of fresh and dry biomass. After harvest, fresh weight was noted while for dry weight, plants were dried in oven at $65^{\circ} \mathrm{C}$ and then dry weight was measured.

\subsection{Soil moisture content}

Soil sample (50 g) from each pot was taken. Fresh weight of soil was noted and soil samples were dried in oven at $105^{\circ} \mathrm{C}$ for $24 \mathrm{~h}$ then dry weight of soil samples was recorded. Then soil moisture content (SMC) was measured by following Formula 1:

$$
\operatorname{SMC}(\%)=\frac{\text { Fresh weight of soil }- \text { Oven dried weight of soil }}{\text { Oven dried weight of soil }} \times 100
$$

\subsection{Relative water content}

Young mature leaves were excised and their fresh weights were noted. Sample leaves were immersed in distilled water and then turgid weight was recorded. Sample leaves were oven-dried and dry weight was recorded. Then relative water content (RWC) was calculated by following Equation 2:

$$
R W C(\%)=\frac{\text { Leaf fresh weight }- \text { Leaf dry weight }}{\text { Leaf turgid weight }- \text { Leaf dry weight }} \times 100
$$

\subsection{Osmotic potential}

Freezed leaf sample was thawed and leaf sap was extracted. After centrifugation, sap was used for determination of osmotic potential by vapour pressure Osmometer (WESCOR 5500, USA).

\subsection{Photosynthetic pigments}

Photosynthetic pigments were extracted in acetone and determined by method of Arnon (1949). $100 \mathrm{mg}$ fresh leaf was homogenized in $5 \mathrm{~mL}$ of $80 \%$ acetone. The homogenate was filtered. The total volume of homogenate was made $20 \mathrm{~mL}$. Absorbance of the leaf extract was recorded by spectrophotometer (Hitachi-U-2900) at 470, 645, 652, 663 and $750 \mathrm{~nm}$ wavelengths. It was assured that extracted samples were of good quality without plant debris as a suspension by accepting absorbance 0-0.009 at $750 \mathrm{~nm}$. Concentrations of different photosynthetic pigment were calculated by following Equations 3, 4, 5, 6:

Chlorophyll a $(\mathrm{mg} / \mathrm{g}$ leaf fwt. $)=[12.7$ (O.D663) -

$2.69($ O.D645] $\times V / 1000 \times W$
Chlorophyll b $(\mathrm{mg} / \mathrm{g}$ leaf fwt. $)=[22.9($ O.D645) $4.68($ O.D663] $\times V / 1000 \times W$

Total Chlorophyll $(\mathrm{mg} / \mathrm{g}$ leaf fwt. $)=$ Chlorophyll $a+$ Chlorophyll b

Carotenoids ( $\mathrm{mg} / \mathrm{g}$ leaf fwt. $)=[1000($ O.D 470) -

$1.91($ Chla $]-95.15($ Chlb)/198

Where O.D is optical density

\subsection{Total soluble proteins}

Total soluble proteins (TSP) were quantified by method of Bradford (1976) by using comassie brilliant blue G-250. For extraction purpose, sodium phosphate buffer was used. Leaf sample extract $(0.1 \mathrm{~mL})$ was mixed with Bradford solution $(5 \mathrm{~mL}$ ) and absorbance was read at $595 \mathrm{~nm}$ by spectrophotometer(UV-1900 BMS). Bovine serum albumin was used as standard soluble protein. TSP were quantified by following Equation 7;

$T S P(\mathrm{mg} / \mathrm{g}$ leaf fwt. $)=\frac{\text { Reading of sample } \times \text { Volume of sample } \times \text { Dilution factor }}{\text { Weight of fresh tissue } \times 1000}$

\subsection{Total free amino acids}

Quantification of total free amino acids (TFAA) was done by method of Van Slyke et al. (1943). After mixing leaf sample extract $(1 \mathrm{~mL}), 10 \%$ Pyridine $(1 \mathrm{~mL})$ and $2 \%$ Ninhydrin $(1 \mathrm{~mL})$, reagents were kept in water bath at about $90{ }^{\circ} \mathrm{C}$ for $30 \mathrm{~min}$. After cooling of mixture, it was diluted with distilled water up to $50 \mathrm{~mL}$. Absorbance was read at $570 \mathrm{~nm}$ on spectrophotometer (UV-1900 BMS). Leucine was used as standard free amino acid. TFAA were quantified by following Equation 8;

$$
\operatorname{TFAA}(\mathrm{mg} / \mathrm{gleaf} \text { fwt } .)=\frac{\text { Reading of sample } \times \text { Volume of sample } \times \text { Dilution factor }}{\text { Weight of freshtissue } \times 1000}
$$

\subsection{Hydrogen peroxide}

$\mathrm{H}_{2} \mathrm{O}_{2}$ estimation in leaves was done by method of (Velikova et al., 2000). Fresh leaf tissue (0.5 g) was homogenized in trichloroacetic acid solution ( $5 \mathrm{~mL}$ ). After centrifugation, supernatant $(0.5 \mathrm{~mL})$, potassium phosphate buffer $(0.5 \mathrm{~mL})$ and $\mathrm{KI}(1 \mathrm{~mL})$ were mixed. Mixture in test tube was vortex and absorbance was read at $390 \mathrm{~nm}$ on spectrophotometer (UV-1900 BMS). The absorbance of reaction mixture was recorded at $390 \mathrm{~nm}$.

\subsection{Malondialdehyde}

Membrane lipid peroxidation was assessed as malondialdehyde content by following Cakmak and Horst (1991). Fresh leaf tissue (1 g) was homogenized in trichloroacetic acid solution $(3 \mathrm{~mL})$. Homogenate was centrifuged at $20000 \mathrm{~g}$ for $15 \mathrm{~min}$. 20\% Trichoroacetic acid containing $0.5 \%$ thiobarbituric acid $(3 \mathrm{~mL})$ was added to leaf sample extract supernatant $(0.5 \mathrm{~mL})$. Mixture was heated in water bath and cooled in ice water bath. Sample mixture was centrifuged and absorbance was read at 532 and $600 \mathrm{~nm}$ on (UV-1900 BMS). The amount of MDA was calculated using following Formula 9 
MDA concentration $($ nano - mole $)=\Delta\left(A_{532 \mathrm{~nm}}-A_{600 \mathrm{~nm}}\right) /$ $1.56 \times 10^{5}$

\subsection{Chlorophyll a fluorescence}

Continuous chlorophyll $a$ fluorescence over one second (OJIP) on the leaves of each Panicum antidotale population was measured using handheld device FluorPen FP100 (PSI, Burno, Czech Republic). The leaves of each Panicum antidotale population were dark adapted for $20 \mathrm{~min}$ to ensure complete oxidation of PSII. A saturation pulse was applied on the dark-adapted leaf (4 mm area) with two light emitting diodes. The length of saturation pulse was $0.8 \mathrm{sec}$ with $3000 \mu$ mole $\mathrm{m}^{-2} \mathrm{~s}^{-1}$. The fluorescence was recorded after every $10 \mu \mathrm{s}$ initially till $2 \mathrm{~ms}$. Fluorescence at different time points was also recorded such as Fo as $\mathrm{O}$ (Fluorescence at 40-50 $\mu \mathrm{s}$ ), FJ or Fluorescence at J (2 ms) point, $\mathrm{F}_{\mathrm{I}}$ or fluorescence at point $\mathrm{I}(30 \mathrm{~ms})$, and fluorescence at point $\mathrm{P}(500 \mathrm{~ms})$ or maximum fluorescence $(\mathrm{Fm})$. The raw curves of OJIP were plotted on log scale. To assess differences in fluorescence under control and stress conditions, raw curves were first normalized by Fo or Fm or by both Fo and Fm values and then their differences were calculated. Both normalized and differential kinetics curves were plotted on log scale. Several JIP-test parameters were obtained from FluorPen 1.1 software (Photon System International, Czech Republic).

\subsection{Leaf potassium}

Accumulation of $\mathrm{K}^{+}$in leaf was determined by method of Allen et al. (1986). After digestion of dry leaf material $(0.1 \mathrm{~g})$, sample was diluted up to $50 \mathrm{~mL}$ and filtered. This filtrate sample was used for estimation of potassium ion with flame photometer (JENWAY PFP 7). Potassium accumulation in leaves was calculated by following Equation 10;

Leaf potassium $(\mathrm{mg} / \mathrm{g} d \mathrm{wt})=.\frac{\text { Reading of sample } \times \text { Volume of sample } \times \text { Dilution factor } \times \text { Molecular weight }}{\text { Weight of dry tissue } \times 1000 \times 1000}$

\subsection{Statistical analysis}

Analysis of variance (ANOVA) of data was determined by using COSTAT, statistical software (Cohort Software, Berkeley, California). Separate ANOVA was determined and means were compared for shoot fresh weight in order to assess masked effect of drought within populations on shoot fresh weight. Mean values were compared with LSD test following Snedecor and Cochran (1989).

\section{Results}

Analysis of variance of the data from all growth parameters shows that water stress had an adverse effect on growth of plants of different populations of $P$. antidotale. For example, imposition of water stress reduced shoot fresh and dry biomass of all $P$. antidotale populations. All populations of $P$. antidotale differed significantly in terms of their fresh and dry weight under water stress and control conditions. Although interaction term 'Drought $\times$ Populations' was significant for shoot fresh weight while populations of $P$. antidotale were statistically similar in their shoot fresh weights under drought condition. It could be due to a strong inhibitory effect of water deficit on shoot fresh weight, which may have masked ecotypic variation among the populations examined in the present study. Thus, a separate ANOVA was computed and means were compared. Analysis showed that maximum shoot fresh weight was found in the population from Multan followed by population from Muzaffargarh. Minimum shoot biomass was found in population from Khanewal. Cholistani populations (Dahranwala, Dingarh Fort, Dingarh Grassland and Haiderwali) were intermediate in shoot fresh weights. Among Cholistani populations, Dahranwala population had lower shoot fresh biomass (Table 1; Figure 1a). Shoot dry weight was also decreased due to water deficit. Under water stress, maximum shoot dry biomass was found in population from Multan, Muzaffargarh, Dingarh Grassland, Haiderwali and Dingarh Fort. Minimum shoot dry biomass was recorded in Khanewal population, while intermediate in Dahranwala population. But high percent decrease in shoot fresh and dry biomass was recorded in non-Cholistan desert populations comparing with Cholistani populations (Table 1; Figure 1b). Data showed that imposition of drought stress caused a considerable decrease in root fresh weights of all populations of $P$. antidotale. Maximum root fresh weight was found in Dingarh Grassland population. Water stress caused a markedly decrease in root dry weight of populations from Multan, Dahranwala and Dingarh Grassland only, whereas root dry weights remained unchanged in other populations due to drought stress (Table 1; Figure 1c, 1d).

Water stress caused a marked reduction in chlorophyll $a$, chlorophyll $b$, total chlorophyll and carotenoids (Table 1 ; Figures 2,3). All populations of $P$. antidotale did not differ significantly with each other in all photosynthetic pigments.

Relative water content (RWC) in leaves of all P. antidotale populations was decreased significantly under imposed water stress. Populations of $P$. antidotale differed in RWC significantly under water stress. Moreover, the interaction term, Drought $\times$ Populations, was also non-significant. Under drought stress, maximum value of RWC was observed in Dahranwala population followed by Haiderwali and Multan. Minimum RWC value was recorded in Dingarh Fort population (Table 1; Figure 4a). Soil moisture content in pots of each $P$. antidotale population was decreased significantly due to three week drought stress. Soil moisture content was similar in the pots of $P$. antidotale populations growing under normal or water stressed conditions (Table 1; Figure 4b). Significant decrease in osmotic potential was recorded in leaves of all $P$. antidotale populations under drought stress. Maximum decrease in osmotic potential due to water stress was recorded in Khanewal population, whereas minimum decrease in osmotic potential was recorded in Dingarh Grassland and Haiderwali populations (Table 1; Figure 4c).

Accumulation of total soluble proteins (TSP) in leaves significantly was increased in Dingarh Grassland and Haiderwali populations of $P$. antidotale only, whereas it remained statistically similar in all other populations. Accumulation of TSP was highest in population from Haiderwali under water stress conditions, whereas 
Table 1. Mean squares from analysis of variance of data for various parameters of seven Panicum antidotale populations, when three weeks old tillers of each population were subjected to drought stress for three weeks.

\begin{tabular}{|c|c|c|c|c|c|c|c|c|c|}
\hline SOV & df & SFW & & SDW & RFW & & RDW & Chl a & Chl b \\
\hline Drought & 1 & $2659.7^{* * *}$ & & $75.4^{* * *}$ & $1117.6^{* * *}$ & & $38.8^{* * *}$ & $0.540^{*}$ & $0.112^{* *}$ \\
\hline Populations & 6 & $72.2^{* *}$ & & $7.8^{* *}$ & $35.7^{* *}$ & & $8.5^{* * *}$ & $0.094 \mathrm{~ns}$ & $0.013 \mathrm{~ns}$ \\
\hline $\begin{array}{c}\text { Drought } \times \\
\text { Populations }\end{array}$ & 6 & $55.4^{* *}$ & & $4.9^{*}$ & $21.5 \mathrm{~ns}$ & & $6.5^{* * *}$ & $0.150 \mathrm{~ns}$ & $0.014 \mathrm{~ns}$ \\
\hline Error & 42 & 15.7 & & 2.0 & 10.2 & & 1.2 & 0.099 & 0.011 \\
\hline Total & 55 & & & & & & & & \\
\hline SOV & df & Chl $a / b$ & Total Chl & & Carotenoids & & Car/Chl & RWC & SMC \\
\hline Drought & 1 & $0.158 \mathrm{~ns}$ & $1.358^{* *}$ & & $25.712^{*}$ & & $2.686 \mathrm{~ns}$ & $17276.1^{* * *}$ & $1721.1^{* * *}$ \\
\hline Populations & 6 & $0.273 \mathrm{~ns}$ & $0.131 \mathrm{~ns}$ & & $2.850 \mathrm{~ns}$ & & $2.253 \mathrm{~ns}$ & $103.0^{*}$ & $22.3 \mathrm{~ns}$ \\
\hline $\begin{array}{c}\text { Drought } \times \\
\text { Populations }\end{array}$ & 6 & $0.257 \mathrm{~ns}$ & $0.281 \mathrm{~ns}$ & & $5.023 \mathrm{~ns}$ & & $3.328 \mathrm{~ns}$ & $46.0 \mathrm{~ns}$ & $15.8 \mathrm{~ns}$ \\
\hline Error & 42 & 0.326 & 0.142 & & 4.142 & & 1.670 & 41.3561 & 12.1 \\
\hline Total & 55 & & & & & & & & \\
\hline SOV & df & OP & TSP & & TFAA & MDA & & $\mathrm{H}_{2} \mathrm{O}_{2}$ & Leaf $\mathbf{K}^{+}$ \\
\hline Drought & 1 & $0.584^{* * *}$ & $35.6^{* * *}$ & & $6.4^{* * *}$ & $149.7^{* * *}$ & & $17857.5^{* * *}$ & $173.5^{* * *}$ \\
\hline Populations & 6 & $0.064^{* * *}$ & $5.8^{*}$ & & $0.9^{* * *}$ & $4.5^{* * *}$ & & $103.3^{* * *}$ & $35.3^{* * *}$ \\
\hline $\begin{array}{l}\text { Drought } \times \\
\text { Populations }\end{array}$ & 6 & $0.075^{* * *}$ & $8.0^{* *}$ & & $0.5^{* * *}$ & $4.1^{* * *}$ & & $346.7^{* * *}$ & $54.3^{* * *}$ \\
\hline Error & 42 & 0.012 & 01.1 & & 0.1 & 0.4 & & 13.4 & 7.4 \\
\hline Total & 55 & & & & & & & & \\
\hline
\end{tabular}

SOV = Source of variance; $\mathrm{df}=$ Degree of freedom; SFW = Shoot fresh weight; SDW = Shoot dry weight; RFW = Root fresh weight; RDW = Root dry weight; Chl $a=$ Chlorophyll $a$; Chl $b=$ Chlorophyll $b$; Chl $a / b=$ Chlorophyll $a / b$ ratio; Total Chl = Total Chlorophyll; Car $/$ Chl = Carotenoid $/$ Chlorophyll ratio; RWC = Relative water content; SMC = Soil moisture content; OP = Osmotic potential; TSP = Total soluble proteins; TFAA = Total free amino acids; $\mathrm{MDA}=$ Malondialdehyde; $\mathrm{H}_{2} \mathrm{O}_{2}=$ Hydrogen peroxide; Leaf $\mathrm{K}^{+}=$Leaf Potassium; $\mathrm{ns}=$ Non-Significant; ${ }^{*},{ }^{* *}$, ${ }^{* * *}$ Significant at $0.05,0.01$ and 0.001 levels respectively.

populations from Muzaffargarh and Dingarh Fort were lowest in this biochemical attribute (Table 1; Figure 5a). Similarly, total free amino acids (TFAA) were enhanced in all $P$. antidotale populations except in populations from Multan and Dingarh Fort. Among all populations, maximum TFAA were found in plants from Haiderwali population. Minimum TFAA were found in plants of Dahranwala populations (Table 1 ; Figure $5 \mathrm{~b}$ ). Water deficit significantly enhanced hydrogen peroxide $\left(\mathrm{H}_{2} \mathrm{O}_{2}\right)$ production and malondialdehyde (MDA) in leaves of all $P$. antidotale populations. Minimal increase in both hydrogen peroxide and malondialdehyde production was found in population from Dingarh Fort. Although maximal $\mathrm{H}_{2} \mathrm{O}_{2}$ production due to water stress was found in populations from Muzaffargarh and Khanewal, both were intermediate in leaf MDA. Similarly, plants of population from Haiderwali had maximal amount of MDA in leaves under water stress conditions, it was intermediate in $\mathrm{H}_{2} \mathrm{O}_{2}$ production (Table 1; Figure 6a, 6b). Under water stress condition, $\mathrm{K}^{+}$accumulation in leaves of populations from Muzaffargarh and Dingarh Fort was increased significantly, whereas it remained same in all other populations. $\mathrm{K}^{+}$accumulation in leaves was maximum in Dingarh Fort and minimum in Khanewal population (Table 1; Figure 6c).
Progressive water stress was imposed on seven $P$. antidotale populations grown is soil culture by withholding water till wilting or leaf rolling at extreme conditions. After 23 days of drought, non Cholistani populations showed complete leaf rolling and these populations could not withstand with more water stress condition. Therefore, these populations were re-watered while Cholistani populations remained under water stress condition. A comparison of photosynthetic potential in different populations of $P$. antidotale was made by assessing PSII structural stability under progressive drought stress using fast chlorophyll $a$ kinetic analysis. Moreover, ability of ecotypes of $P$. antidotale to recover from PSII photoinhibition or photo-damage upon rehydration was also made. Structural stability of PSII to water stress was assessed using semi-quantitative and quantitative analysis. From the results of raw OJIP curves, differential kinetics of double normalized curves between O-P phases, it is clear that drought stress caused a significant change in the shape of OJIP curves over progressive drought in all ecotypes/ populations of $P$. antidotale (Figures 7,8 ) However, in nonCholistani populations such changes appeared after 19 days of progressive drought, whereas in Cholistani populations such changes appeared after 31 days of progressive drought indicating that Cholistani populations had greater ability 


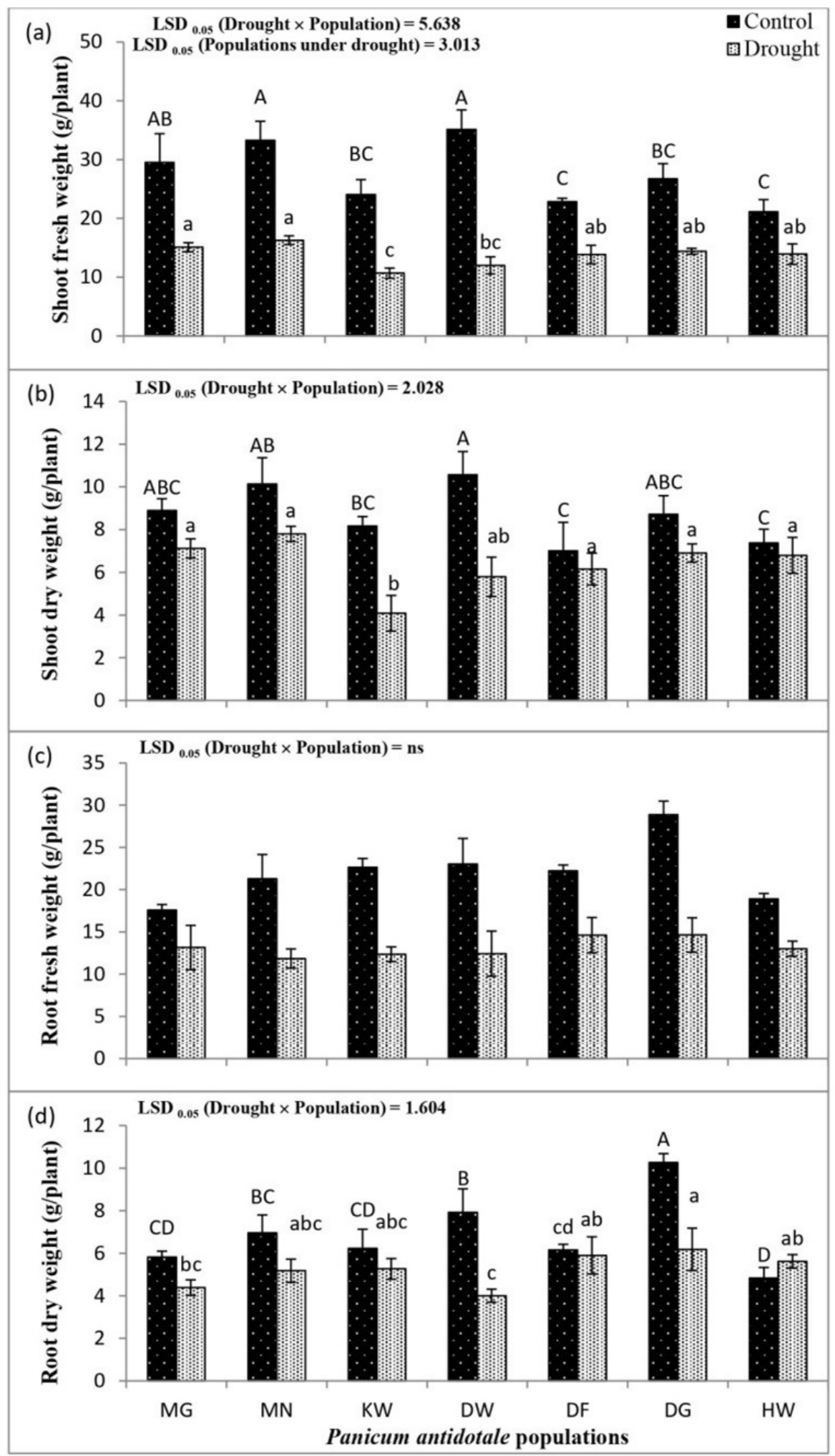

Figure 1. (a) Shoot fresh weight, (b) shoot dry weight, (c) root fresh weight and (d) root dry weight of seven Panicum antidotale populations, when three weeks old tillers of each population were subjected to drought stress for three weeks. MG = Muzaffargarh; MN = Multan; KW = Khanewal; DW = Dahranwala; DF = Dingarh Fort; DG = Dingarh Grassland; HW = Haiderwali; LSD0.05 = Least significant difference at 5\%; ns = Non significant; Error bars represent standard error; Mean \pm S.E; Means of populations in control conditions are compared with capital letters while means of populations in saline conditions are compared with small letters. 


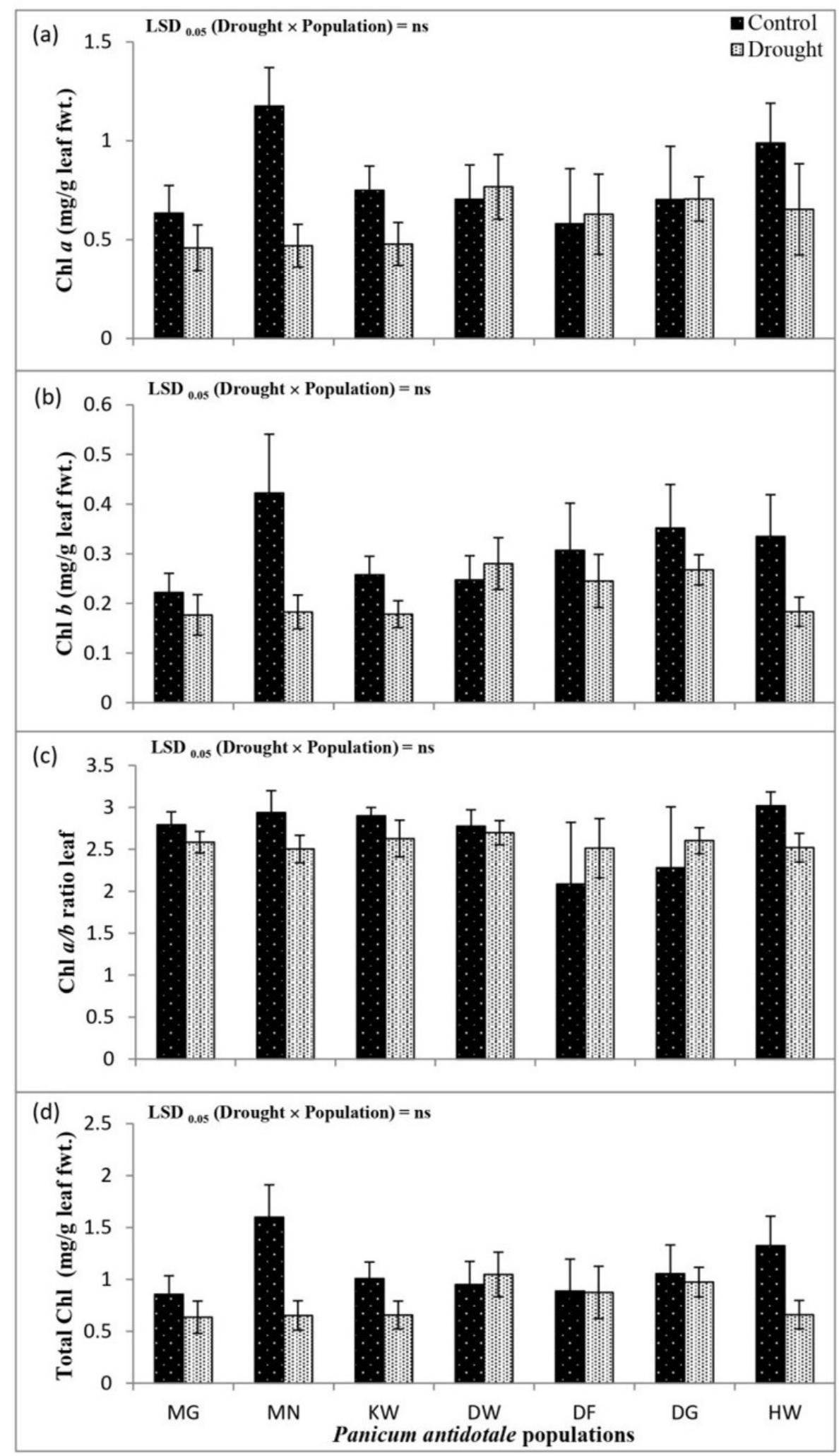

Figure 2. (a) Chlorophyll $a$, (b) chlorophyll $b$, (c) chlorophyll $a / b$ ratio and (d) total chlorophyll of seven Panicum antidotale populations, when three weeks old tillers of each population were subjected to drought stress for three weeks. MG = Muzaffargarh; MN = Multan; KW = Khanewal; DW = Dahranwala; DF = Dingarh Fort; DG = Dingarh Grassland; HW = Haiderwali; LSD0.05 = Least significant difference at 5\%; ns = Non significant; Error bars represent standard error; Mean \pm S.E. 


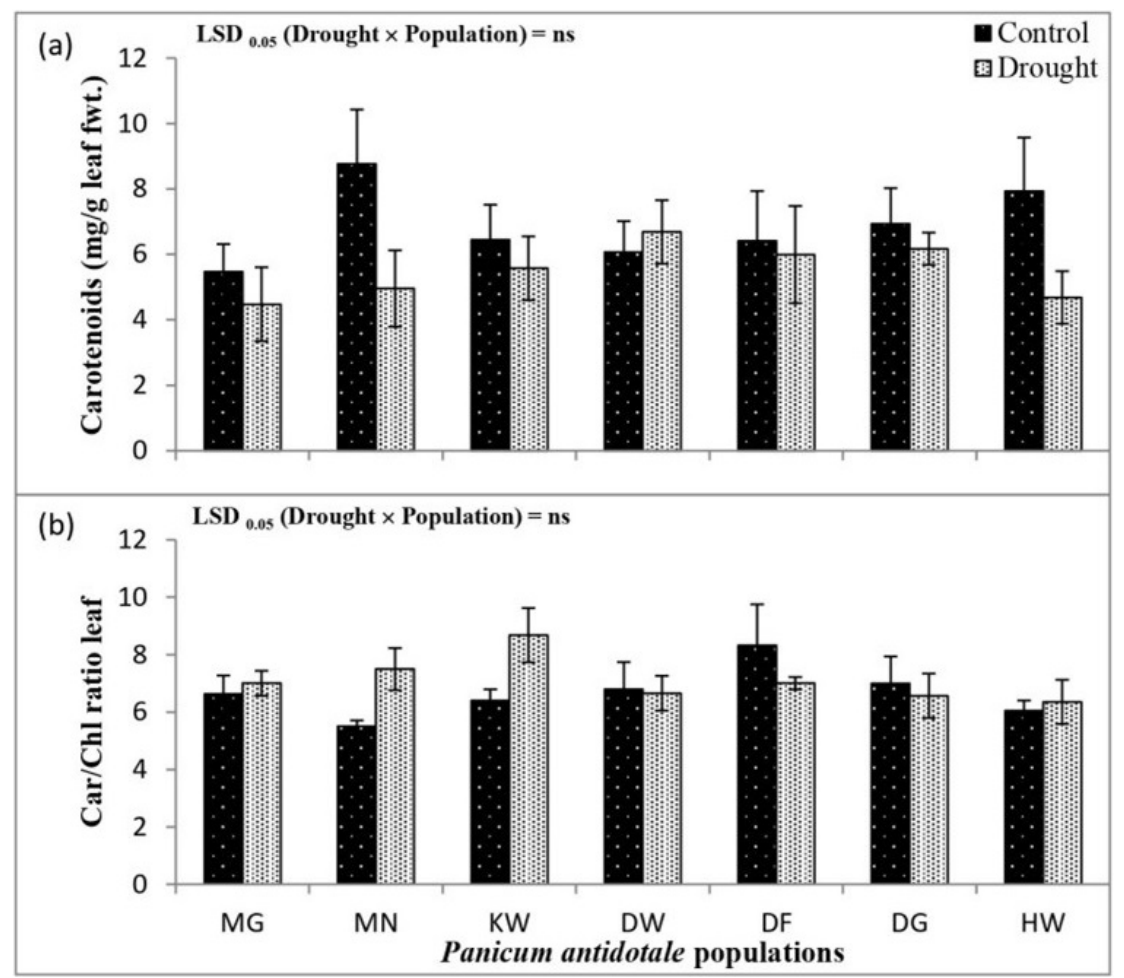

Figure 3. (a) Carotenoids and (b) carotenoids/chlorophyll ratio of seven Panicum antidotale populations, when three weeks old tillers of each population were subjected to drought stress for three weeks. MG = Muzaffargarh; MN = Multan; KW = Khanewal; DW= Dahranwala; DF = Dingarh Fort; DG = Dingarh Grassland; HW = Haiderwali; LSD0.05 = Least significant difference at 5\%; ns = Non significant; Error bars represent standard error; Mean \pm S.E.

to protect PSII over longer period of progressive drought. Differential kinetics of double normalized curves showed that a significant increase in fluorescence at $\mathrm{K}$ (stability of oxygen evolving complex), J(energetic connectivity of PSII core-complex with antennae) and I (re-reduction of PQ pool by PSI activity) phases after 19 and 23 days of progressive drought in all non Cholistani P. antidotale populations (Muzaffargarh, Multan and Khanewal). After 24 hours of rehydration, population from Khanewal gets recovered completely while population that from Multan partially recovered. Moreover, population from Muzaffargarh did not recovered from changes in fluorescence at $\mathrm{K}$, J and I steps indicating damages to PSII at donor and acceptor end of PSII or blockage in intersystem electron transport to drought stress (Figures 7, 8).

After 29 and 31 days of progressive drought, a significant increase in fluorescence at $\mathrm{K}$, J or I phases was found in populations those from Cholistan (Dahranwala, Dingarh Fort, Dingarh Grassland and Haiderwali). On D29, among Cholistani populations, $\mathrm{K}$ phase appeared in population from Dahranwala, J phase appeared in Dingarh Grassland while I phase appeared in all four populations. However, fluorescence rise at I phase was more in Dingarh Grassland population followed by the populations from Haiderwali and Dahranwala while less in Dingarh Fort. After 24 hours of rehydration, among Cholistani populations, changes in fluorescence at $\mathrm{K}, \mathrm{J}$ and I phases did further increase in fluorescence in populations those from Dahranwala and Dingarh Fort while changes in fluorescence remained same in populations those from Dingarh Grassland and Haiderwali. These results indicated that drought stress caused the blockage of intersystem electron transport that lead to PSII irreversible photo-inhibition of PSII in populations from Dahranwala, Dingarh Fort and Dingarh Grassland. However, such drought induced damages to intersystem electron transport in population from Haiderwali lead to least photo-inhibition. From these results, it is suggested that all four Cholistani populations had less ability to recover PSII activity after 24 hours of rehydration except population from Haiderwali (Figures 7, 8).

Progressive drought stress caused a significant increase in Fo, Fj, Fi and Fm in all seven grass populations of $P$. antidotale. Overtime, fluorescence at all these steps was decreased significantly. However, 24 hours after rehydration both parameters of basic fluorescence were decreased as compared to 15 days water stressed plants of all seven grass populations except that from Muzaffargarh (Table 2).

Drought stress caused significant increase in relative variable fluorescence at $\mathrm{J}$ and I steps of plants of all populations of $P$. antidotale. Maximum increase in both these parameters was found in populations from Muzaffargarh and Multan. Among Cholistani populations, 


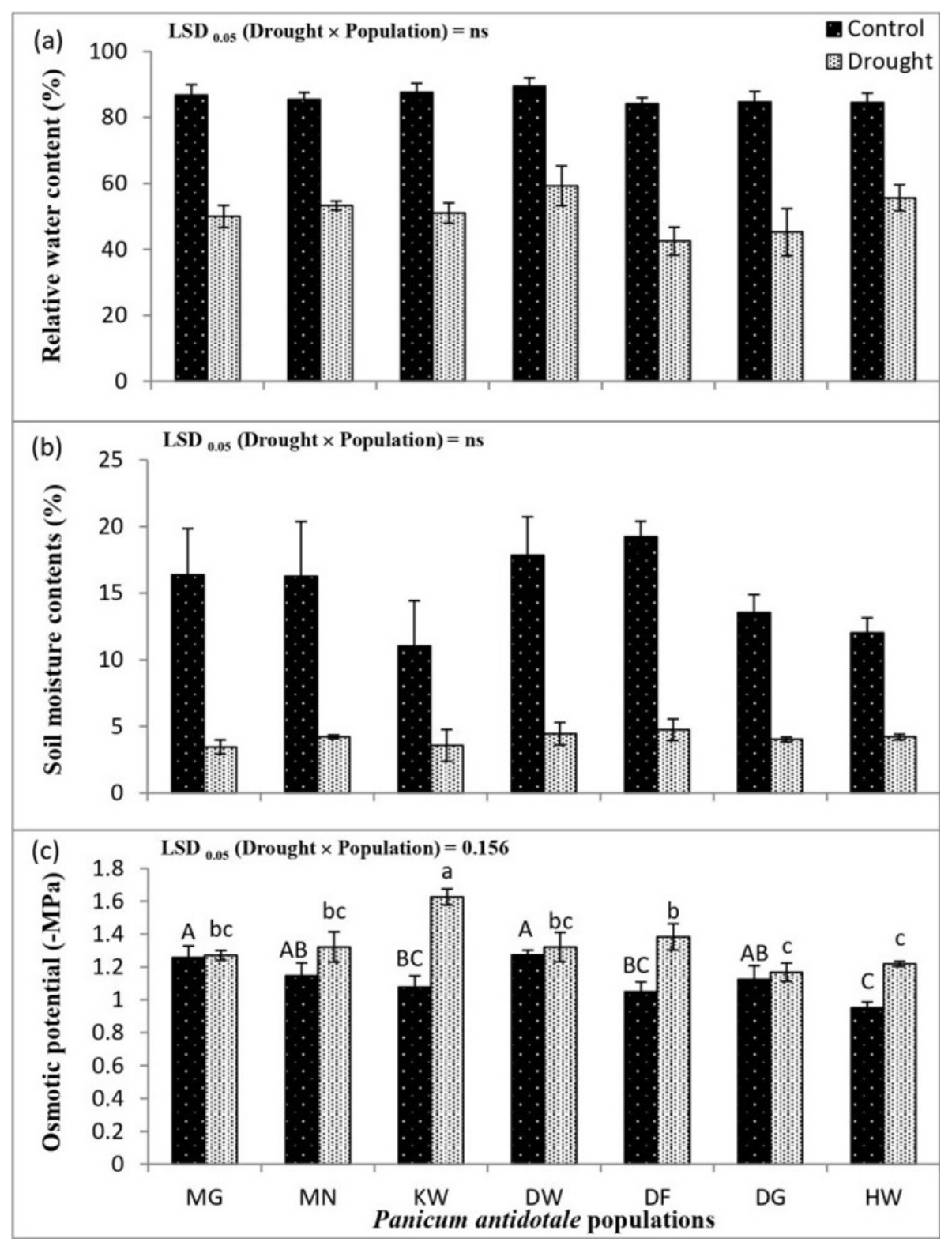

Figure 4. (a) Relative water content, (b) soil moisture content and (c) osmotic potential of seven Panicum antidotale populations, when three weeks old tillers of each population were subjected to drought stress for three weeks. MG = Muzaffargarh; MN = Multan; KW = Khanewal; DW = Dahranwala; DF = Dingarh Fort; DG = Dingarh Grassland; HW = Haiderwali; LSD0.05 = Least significant difference at $5 \%$; ns = Non significant; Error bars represent standard error; Mean \pm S.E; Means of populations in control conditions are compared with capital letters while means of populations in saline conditions are compared with small letters.

population that from Haiderwali showed a minimal increase in relative variable fluoresce at J and I steps (Table 2)

Short term drought stress did not affect PSII quantum yield of all seven populations of $P$. antidotale. Prolong drought stress caused a significant decrease $(P<0.05)$ in quantum yield of PSII (Fv/Fm) and stability of oxygen evolving complex (Fv/Fo) in all populations of $P$. antidotale (Table 2). Rate of reduction of QA (Mo), fraction of reduced PQ pool (Area) and PQ pool (Fix area) were significantly increased due to drought stress. Rate of reduction of QA or
PSII closure along with fraction of reduced PQ pool were maximum in water stressed plants of populations those from Muzaffargarh, Multan and Khanewal. However, pool of PQ was greater in water stressed plants of populations those from Cholistan desert (Table 2).

Performance index $\mathrm{PI}_{\mathrm{ABS}}$ was significantly reduced due to progressive water stress in all seven populations of $P$. antidotale. Maximum reduction in $\mathrm{PI}_{\mathrm{ABS}}$ due to drought stress was found in non-Cholistani populations. Among Cholistani populations, plants of population from Haiderwali had 


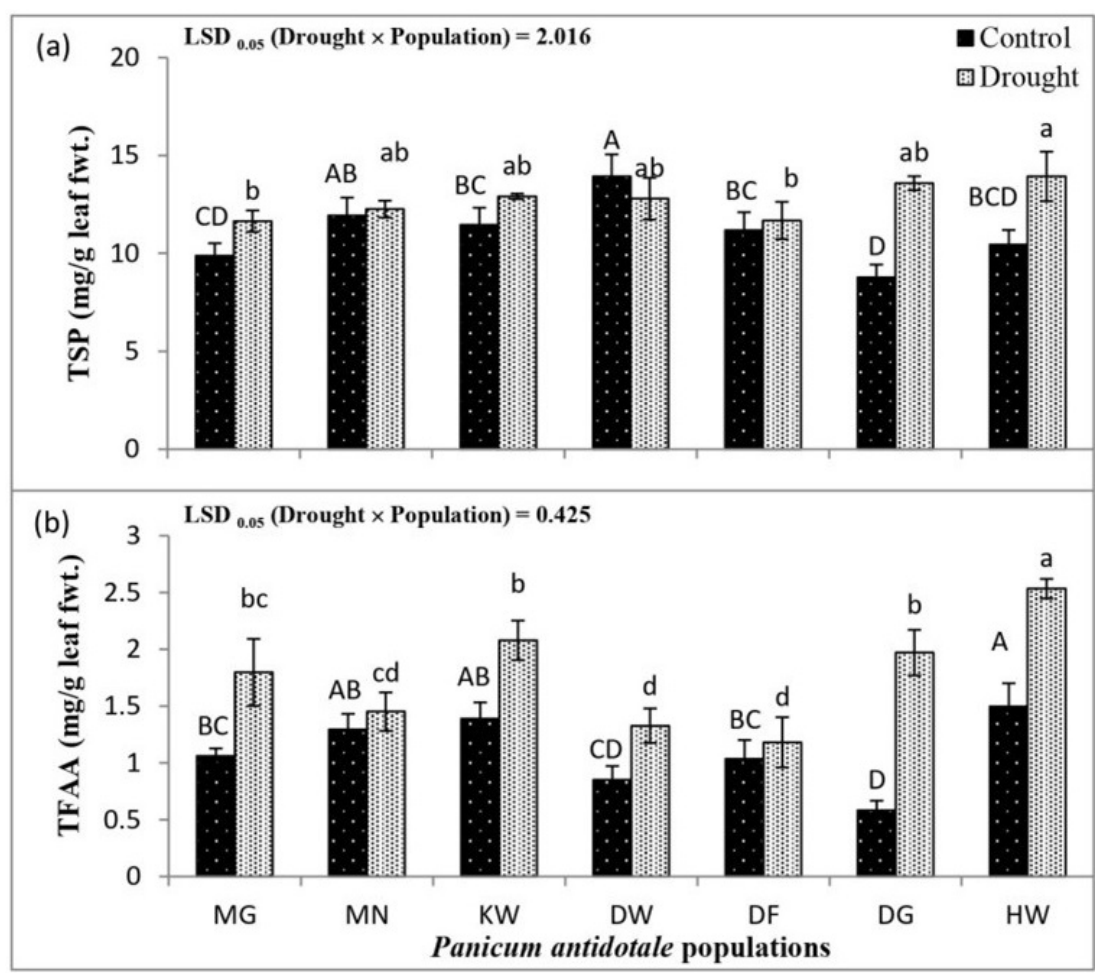

Figure 5. (a) Total soluble proteins (TSP) and (b) total free amino acids (TFAA) seven Panicum antidotale populations, when three weeks old tillers of each population were subjected to drought stress for three weeks. MG = Muzaffargarh; MN = Multan; KW = Khanewal; DW = Dahranwala; DF = Dingarh Fort; DG = Dingarh Grassland; HW = Haiderwali; LSD0.05 = Least significant difference at 5\%; Error bars represent standard error; Mean \pm S.E; Means of populations in control conditions are compared with capital letters while means of populations in saline conditions are compared with small letters.

maximal $\mathrm{PI}_{\mathrm{ABS}}$ under maximum duration of water stress condition (Table 2). Of various bioenergetics fluxes, ABS/ $\mathrm{RC}$ and TRo/RC were increased with progressive drought stress while ETo/RC was decreased considerably. However, populations did not differ in ETo/RC under normal or water stressed conditions. Moreover, DIo/RC was increased considerably in non-Cholistani populations of $P$. antidotale due to progressive drought stress (Table 2). Active reaction centre density was decreased due to progressive drought in all populations. However, this decrease was maximal in populations that from Muzaffargarh and Multan.

\section{Discussion}

Plants inhabiting in drought hit areas such as grasses are adapted to water deficit conditions and proposed to use in identifying mechanisms of drought tolerance. In the present study, seven $P$. antidotale populations were collected from habitats (with varying soil water status) were examined for drought tolerance. Natural populations were collected from different regions of Cholistan (Dahranwala, Dingarh Fort, Dingarh Grassland and Haiderwali) and non-Cholistan areas (Muzaffargarh, Multan and Khanewal). During the study, it has been found that growth of all seven $P$. antidotale populations was reduced under low moisture regime. Though, populations from non-cholistani regions had relative lower growth than populations from Cholistan regions under drought condition. Non-cholistani population from Muzaffargarh and Cholistani population that from Haiderwali had greater dry biomass under drought stress. Greater water stress tolerance in populations from Muzaffargarh and that from Haiderwali can be related to their adaptive potential to their dry habitats. Habitats of these two sites are drier than those of other habitats. Moreover, drought stress sensitivity in populations from Khanewal and Multan can be related to adaptation to available soil moisture content.

From these results and already published reports, variation in drought tolerance in $P$. antidotale populations collected from different habitat/sites may have been due to different selection pressure of availability of water in different habitat (Bennington and McGraw, 1995; Dudley, 1996a, b; Heschel et al., 2002). Plants responses to water stress are very complex and natural populations develop multitude morpho-physiological characteristics which enable the plants to cope with extreme environmental conditions including drought stress. Drought stress affects elongation and expansion growth (Jaleel et al., 2009). Present study findings are similar to some of the earlier studies in which genetic variability for drought tolerance has been documented such as in grasses (Ashraf and Yasmin, 1995), P. antidotale (Shahbaz et al., 2012) and Zea mays cultivars (Ashraf et al., 2007). 

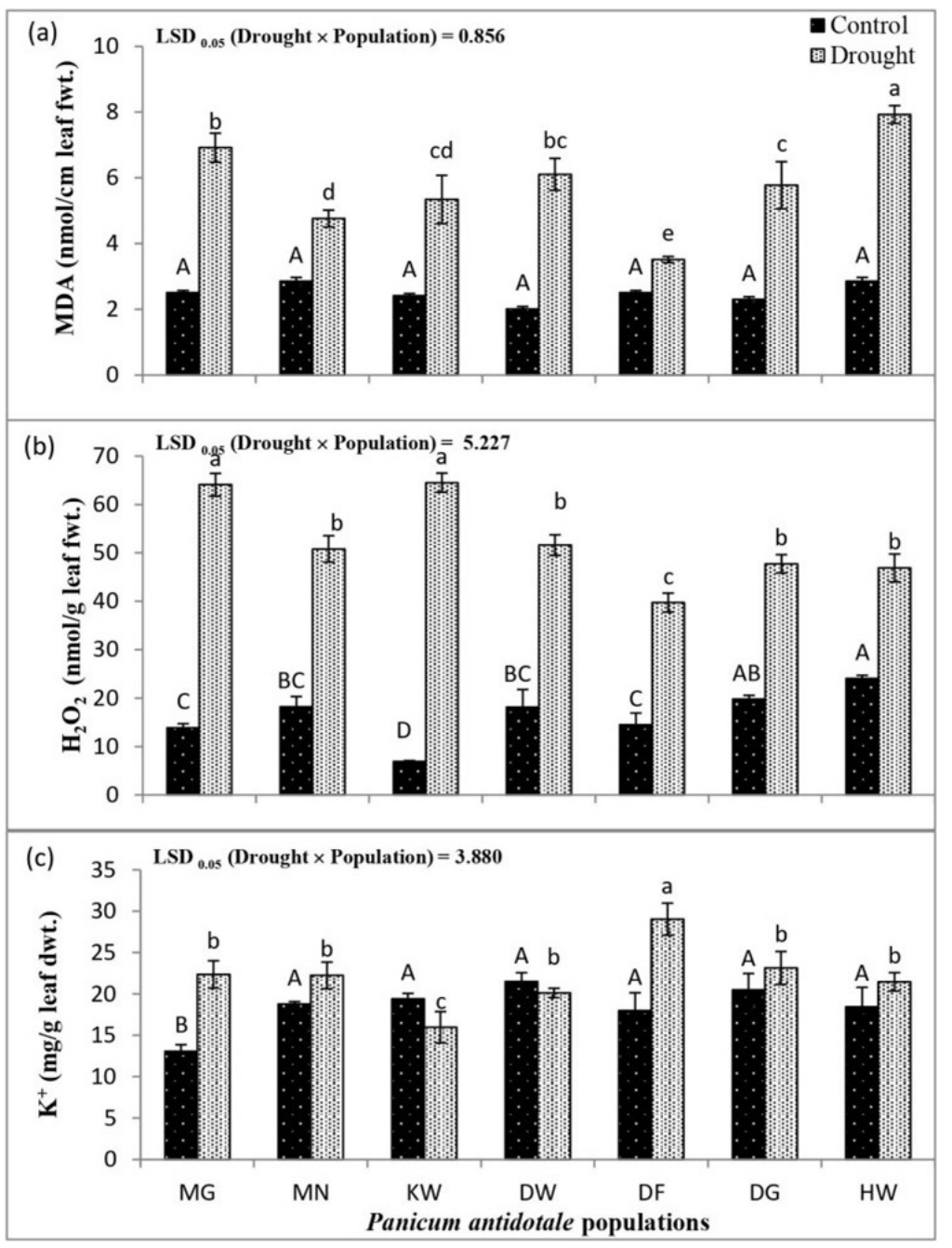

Figure 6. (a) Malondialdehyde (MDA), (b) Hydrogen peroxide $\left(\mathrm{H}_{2} \mathrm{O}_{2}\right)$ and (c) potassium ( $\left.\mathrm{K}^{+}\right)$accumulation in seven Panicum antidotale populations, when three weeks old tillers of each population were subjected to drought stress for three weeks. MG = Muzaffargarh; MN = Multan; KW = Khanewal; DW = Dahranwala; DF = Dingarh Fort; DG = Dingarh Grassland; HW = Haiderwali; LSD0.05 = Least significant difference at 5\%; ns = Non significant; Error bars represent standard error; Mean \pm S.E; Means of populations in control conditions are compared with capital letters while means of populations in saline conditions are compared with small letters.

Two important aspects which are interlinked with each other are growth and photosynthesis. Chlorophyll is an important component of chloroplast which is necessary for photosynthesis. Under water stress, reduction in chlorophyll content is usually considered as sign of oxidative stress. It may be due to photooxidation of pigment and degradation of chlorophyll (Huseynova et al., 2009). Results from present study show that drought stress caused marked reduction in photosynthetic pigments ( $\mathrm{Chl} a, \mathrm{Chl} b$, total $\mathrm{Chl}$ and carotenoids) in leaves of all $P$. antidotale populations. Reduction in photosynthetic pigments might be due to reduced synthesis of chlorophyll or chlorophyll binding proteins LHC (Allakhverdiev et al., 2003) or increase in chlorophyll degradation by increase in chlorophyllase enzyme or chlorophyll degradation by singlet oxygen generation under water stress (Krieger-Liszkay, 2005).
From the results, it is suggested that population tolerant to water stress had greater ability to protect photosynthetic pigments from photooxidative damage or higher rate of biosynthesis under drought stress.

Maintenance of plant water status for sustained growth is essential and relative water content (RWC) is more important physiological indicator for the assessment of plant water status than any other water relation parameters under water deficit conditions (Boyer et al., 2008). Drought tolerant or Cholistani populations of $P$. antidotale had greater RWC. Similarly, minimum reduction in osmotic potential was observed in Cholistani populations Dingarh Grassland and Haiderwali. Lowering of osmotic potential due to net solute accumulation in response to water stress has been observed in drought tolerant populations. Under stressful condition, osmotic adjustment may also 


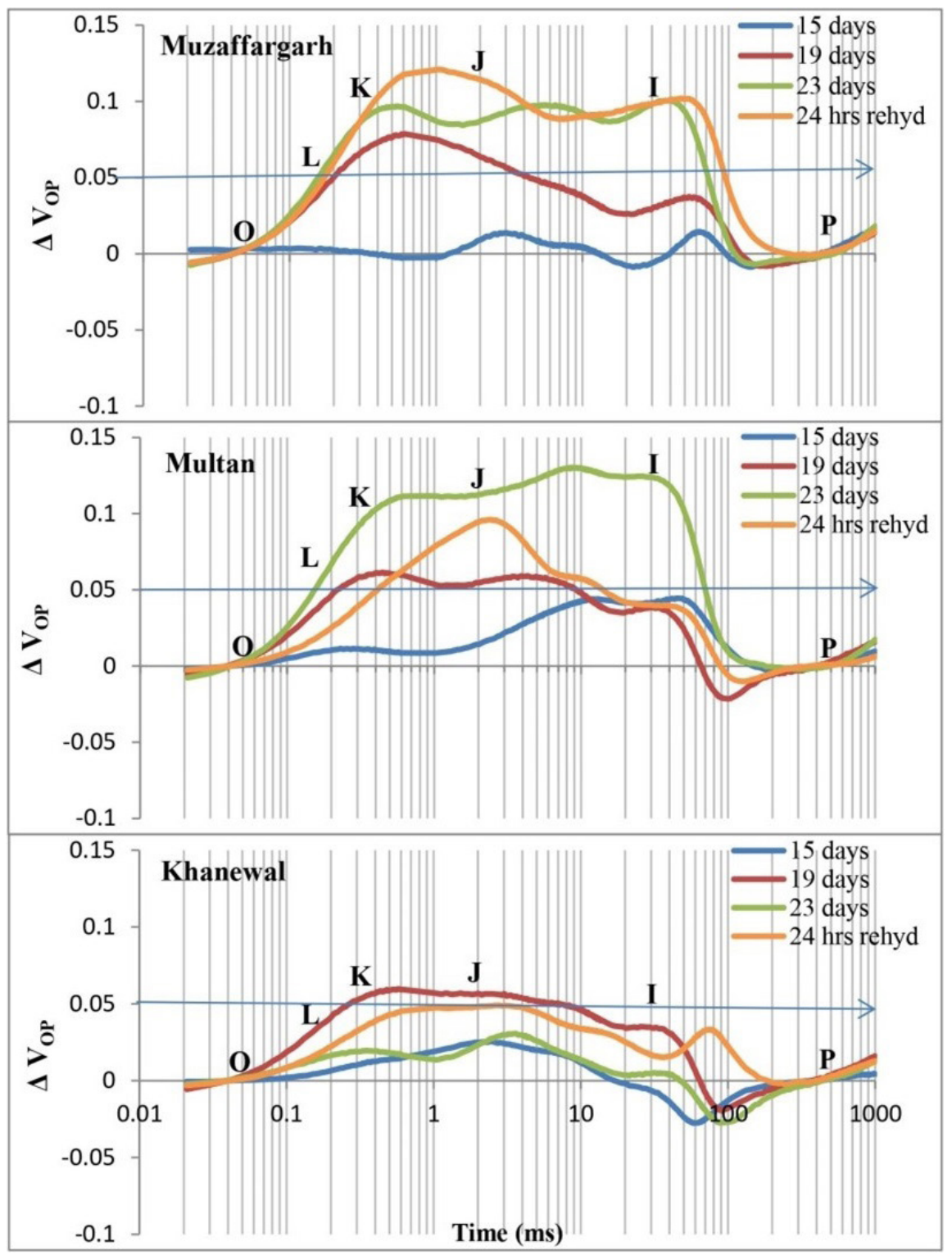

Figure 7. Differential kinetics of fast chlorophyll a fluorescence analysis $\Delta \mathrm{V}_{\mathrm{OP}}$ of non Cholistani Panicum antidotale populations, when three weeks old tillers of each population were subjected to drought stress for various days.

be favoured by solutes like accumulation of total soluble proteins, total free amino acids and soluble sugars. In our study accumulation of total soluble proteins in the leaves was significantly increased in Dingarh Grassland and Haiderwali populations of $P$. antidotale only. Similarly, total free amino acids were increased in all $P$. antidotale populations except in populations from Multan and Dingarh Fort. These results are similar to some earlier findings in which it has been observed that progressive drought increased the total free amino acids in wheat (Lawlor, 2002). Accumulation of total soluble proteins and total free amino acids are directly related with leaf osmotic potential and thus water status of leaf. Therefore, P. antidotale populations from Haiderwali and Dingarh
Grassland might have maintained their water status with increase in total soluble proteins and total free amino acids concentration under water stress. Remarkable osmotic adjustment was observed during study in Jatropha curcas (Silva et al., 2010). From our results we can suggest that $P$. antidotale populations from Dingarh Grassland and Haiderwali have better ability of osmotic adjustment as compare to population from Khanewal under water stress.

Drought stress causes the oxidative stress by generation of ROS species in various cellular organelles including chloroplast and thus reduced the photosynthetic capacity. Plant species tolerant to oxidative stress have greater photosynthetic efficiency. In this study, drought stress increased hydrogen peroxide $\left(\mathrm{H}_{2} \mathrm{O}_{2}\right)$ and membrane 


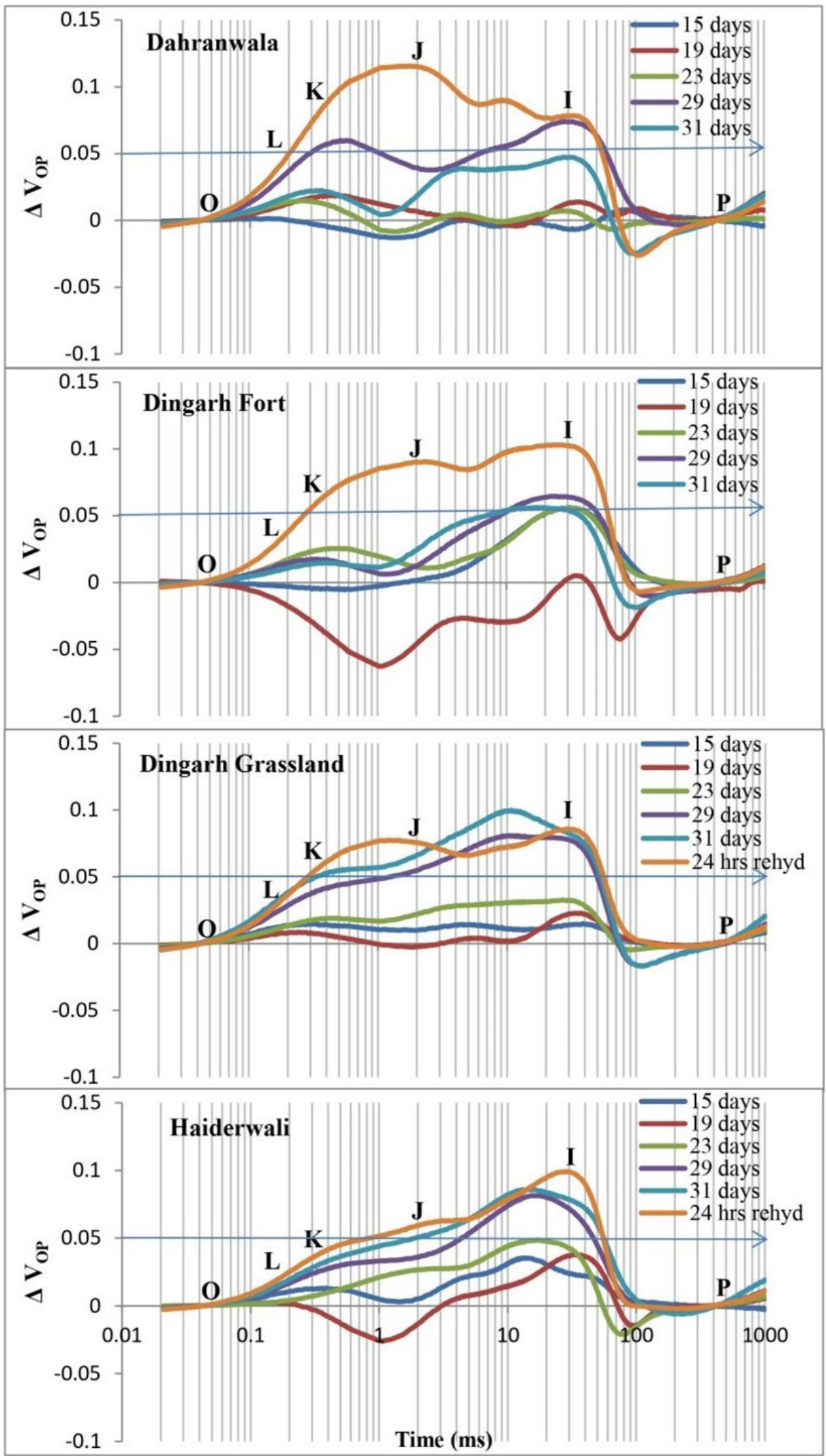

Figure 8. Differential kinetics of fast chlorophyll $a$ fluorescence analysis $\Delta \mathrm{V}_{\mathrm{op}}$ of Cholistani Panicum antidotale populations, when three weeks old tillers of each population were subjected to drought stress for various days. 
Table 2. Mean squares from analysis of variance of data for OJIP parameters of seven Panicum antidotale populations, when three weeks old tillers of each population were subjected to drought stress for various days.

\begin{tabular}{|c|c|c|c|c|c|}
\hline SOV & df & Fo & $\mathbf{F j}$ & $\mathbf{F i}$ & Fm \\
\hline Populations & 6 & 1239690.2ns & $6506784 n s$ & $11630517 \mathrm{~ns}$ & 33708020ns \\
\hline Drought & 1 & $71019130^{* * *}$ & $4.8259^{* * *}$ & $8.49253^{* * *}$ & $6.3791^{* * *}$ \\
\hline Duration & 3 & $69180781^{* * *}$ & $8.6279^{* * *}$ & $1.72628^{* * *}$ & $2.9765^{* * *}$ \\
\hline Populations $\times$ Drought & 6 & $3121082.2^{* * *}$ & $30508835^{* * *}$ & $61182624^{* *}$ & $62399878^{*}$ \\
\hline Populations $\times$ Duration & 18 & $1206621.6^{*}$ & 8539261.4ns & $18640956 n s$ & $30960855 n s$ \\
\hline Drought $\times$ Duration & 3 & $9751252.9^{* * *}$ & $82151661^{* * *}$ & $1.1255^{* * *}$ & $1.2205^{* *}$ \\
\hline Populations $\times$ Drought $\times$ Duration & 18 & $3030085^{* * *}$ & $29643234^{* * *}$ & $63104429^{* * *}$ & $76164003^{* * *}$ \\
\hline Error & 392 & 612090.04 & 7093298.1 & 18285644 & 25202719 \\
\hline Total & 447 & & & & \\
\hline SOV & df & Fv/Fo & $\mathbf{F v} / \mathbf{F m}$ & Mo & $\mathbf{P I}_{\mathrm{ABS}}$ \\
\hline Populations & 6 & $1.6757^{* * *}$ & $0.0048^{* * *}$ & $0.0867^{* * *}$ & $6.0623^{* * *}$ \\
\hline Drought & 1 & $10.0586^{* * *}$ & $0.0333^{* * *}$ & $1.6852^{* * *}$ & $80.8137^{* * *}$ \\
\hline Duration & 3 & $6.5188^{* * *}$ & $0.0140^{* * *}$ & $0.6056^{* * *}$ & $5.8465^{* * *}$ \\
\hline Populations $\times$ Drought & 6 & $0.8959^{* *}$ & $0.0030^{* *}$ & $0.0941^{* * *}$ & $3.2926^{* * *}$ \\
\hline Populations $\times$ Duration & 18 & $0.3667 \mathrm{~ns}$ & $0.0009 \mathrm{~ns}$ & $0.0135 n s$ & $0.9683^{*}$ \\
\hline Drought $\times$ Duration & 3 & $0.9921^{*}$ & $0.0024^{*}$ & $0.1639^{* * *}$ & $11.9201^{* * *}$ \\
\hline Populations $\times$ Drought $\times$ Duration & 18 & $0.1749 \mathrm{~ns}$ & $0.0005 n s$ & $0.0326^{* * *}$ & $0.8276^{*}$ \\
\hline Error & 392 & 0.2660 & 0.0008 & 0.0096 & 0.5013 \\
\hline Total & 447 & & & & \\
\hline SOV & df & ABS/RC & TRo/RC & ETo/RC & DIo/RC \\
\hline Populations & 6 & $0.1227^{*}$ & $0.0399 \mathrm{~ns}$ & $0.0759^{* * *}$ & $0.0495^{* *}$ \\
\hline Drought & 1 & $6.2056^{* * *}$ & $2.3391^{* * *}$ & $0.0534^{* *}$ & $0.9256^{* * *}$ \\
\hline Duration & 3 & $2.3343^{* * *}$ & $2.1024^{* * *}$ & $0.5458^{* * *}$ & $0.0394^{*}$ \\
\hline Populations $\times$ Drought & 6 & $0.3565^{* * *}$ & $0.1335^{* * *}$ & $0.0096 n s$ & $0.0637^{* * *}$ \\
\hline Populations $\times$ Duration & 18 & $0.0711 \mathrm{~ns}$ & $0.0289 \mathrm{~ns}$ & $0.0084 \mathrm{~ns}$ & $0.0147 \mathrm{~ns}$ \\
\hline Drought $\times$ Duration & 3 & $0.4252^{* * *}$ & $0.1678^{* * *}$ & $0.0528^{* * *}$ & $0.0621^{* *}$ \\
\hline Populations $\times$ Drought $\times$ Duration & 18 & $0.1119^{* *}$ & $0.0592^{* * *}$ & $0.0106^{*}$ & $0.0137 \mathrm{~ns}$ \\
\hline Error & 392 & 0.0461 & 0.0193 & 0.0056 & 0.0132 \\
\hline Total & 447 & & & & \\
\hline
\end{tabular}

SOV = Source of variance; $\mathrm{df}=$ Degree of freedom; ns = Non-Significant; ${ }^{*},{ }^{* *},{ }^{* * *}$ Significant at $0.05,0.01$ and 0.001 levels respectively.

damage (measured as Malondialdehde, MDA) in leaves of $P$. antidotale populations. MDA is a product of lipid peroxidation (decomposition of polysaturated fatty acids of biomembranes) and it is considered as sign of oxidative damage. Therefore, its increased concentration shows plants under stress (Pan et al., 2006). Hydrogen peroxide is potential biochemical oxidative stress in plants as membrane damages mainly occur due this toxic substance (Foyer, 2018). The difference in responses of lipid peroxidation and hydrogen peroxide concentration in leaves of $P$. antidotale populations is associated with drought stress tolerance level.

Mineral nutrients are required by plant for growth and development (Marschner, 1995). Water stress causes reduction in uptake of mineral nutrients in plants (Marschner, 1995; Baligar et al., 2001). Drought resistant plants usually show minor reduction in nutrients absorption (Garg, 2003; Gunes et al., 2006). Potassium has various physiological roles in drought stress tolerance in plants such as osmoregulation, photosynthesis, protein synthesis etc. (Khan et al., 1999). Alam (1994) reported that plant root growth and potassium diffusion are influenced by soil moisture content. In our results, $P$. antidotale populations showed significant difference in $\mathrm{K}^{+}$accumulation in leaves. Under drought stress, drought tolerant populations those from Muzaffargarh and Dingarh Fort had greater $\mathrm{K}^{+}$accumulation in their leaves. Shahbaz et al. (2012) also demonstrated that drought tolerant population of $P$. 
antidotale had greater ability to accumulate $\mathrm{K}^{+}$in leaves under water stress. Likewise, Tanguilig et al. (1987) found greater $\mathrm{K}^{+}$uptake in drought tolerant maize cultivars. Long ago, it has been demonstrated that drought tolerant plants had better ability for uptake and accumulation of macronutrients such as N, P and K under drought stress conditions such as chickpea (Gunes et al., 2006), grasses (Akram et al., 2008) and soybean (Samarah et al., 2004).

Progressive drought caused the gradual depletion of soil moisture which had negative effects of leaf water status and photosynthetic activity of all populations of $P$. antidotale. It is suggested that adverse effects of drying soil on photosynthesis was mainly due to higher level of leaf dehydration. Progressive drought caused PSII damages after 19 days and it became severe after 23 days in non-Cholistani populations of $P$. antidotale as revealed by several changes in OJIP raw curves and differential kinetics of double normalized curves between $\mathrm{O}$ and $\mathrm{P}$ time points. However, in Cholistani populations such damages appeared after almost one month. These differences were possibly due to differences in maintenance of plant water status in both these types of populations. Comparison of OJIP curves and JIP-test parameters indicated extent of damages to different sites of PSII such as antenna and core protein, donor and acceptor site of PSII and reaction centre. Moreover, it also reveals about inhibition in electron transport. For example, drought increased Fo in non-Cholistani populations after 19 and 23 days of drought stress whereas no significant change was found Cholistani populations. This increase in Fo can be reasoned to either due to structural damage at antenna and core protein leading to lower energy transfer from antenna to reaction centre or inactivation of reaction centre (Redillas et al., 2011; Goltsev et al., 2012). Moreover, increase in relative variable fluorescence at $\mathrm{J}$ step $(\mathrm{VJ})$ and appearance of $\mathrm{K}$ band $(\Delta \mathrm{OJ})$ in non-Cholistani populations after 19 and 23 days of drought suggested that antenna complex and core proteins of PSII in Cholistani population remain intact over longer period of time. Moreover, Cholistani populations of $P$. antidotale had greater ability to resist an imbalance in electron transfer from donor end to accepter side to PSII caused by the drought stress as has been earlier report in wheat (Zivcak et al., 2014). Changes in fluorescence at I step indicates oxidation/ reduction status of PQ pool (Ceppi et al., 2012) and drought stress caused over-reduction of PQ pool in all populations of $P$. antidotale. Such adverse effects appeared earlier in non-Cholistani populations. This result indicated that Cholistani populations were better capable to maintain rate of $\mathrm{PQ}$ pool reduction as has been found in some drought tolerant genotypes of barley (Rapacz et al., 2019), rapeseed (Lotfi et al., 2018), grapes (Wang et al., 2012, 2015) and mango (Helaly et al., 2017). Changes in fluorescence in I-P phase indicated the electron flux from $\mathrm{PQH}_{2}$ to PSI end electron acceptors (Bussotti, 2004; Guha and Reddy, 2014; Bussotti et al., 2020). Severe drought stress reduced this phase after 23 days of water stress in non-Cholistani populations which might have been due to severe reduction in leaf water status. The energy transformation status in reaction center was assessed by calculating energy flux per active reaction center (Strasser et al., 2000, 2004, 2007; Stirbet and Govindjee, 2011; Goltsev et al., 2012).
Drought stress increased the energy fluxes for absorption, trapping and electron transfer per active reaction center. It is suggested that such increase in absorption energy flux can be related to inactivation of reaction centers or regrouping of antenna of inactive PSII reaction centers to active PSII reaction centers (Strasser et al., 2000, 2004, 2007). Moreover, quantum yield of probability of electron transfer further than QA reduced substantially particularly in non-Cholistani population indicating inhibition or down regulation of electron transfer thereby resulting in increase in heat dissipation per active reaction center (Guha et al., 2013; Guha and Reddy, 2014). This lowering in electron transport facilitated Cholistani populations in lesser over-reduction of electron acceptors and photo-oxidative PSII damage (Zivcak et al., 2013). Difference in energy fluxes for absorption, electron transfer and dissipation might have contributed in photoprotection of PSII under severe drought stress. Moreover, this ability was greater in Cholistani populations.

\section{Conclusion}

Water stress is important environmental factor that cause reduction in plant growth of $P$. antidotale. Moreover, considerable variation has been observed in populations of $P$. antidotale for drought tolerance. Populations of $P$. antidotale that from Cholistan showed better growth under water stress conditions as compared to that from other than Cholistan desert. Better ability to maintain leaf water status was probably due osmotic adjustment. However, drought sensitive population that from Khanewal was unable to maintain turgor despite having lower osmotic potential. Water stress decreased the photosynthetic pigments and activity of photosystem-II (PSII). However, greater drought tolerance in Cholistani populations was associated with protection from oxidative damage and greater PSII stability and functionality. Similarly, progressive drought stress caused leaf wilting by lowering in soil moisture content, lower water uptake and thus lower leaf water content, increase in oxidative stress and decrease in PSII activity. Such adverse physiological changes over three weeks caused reduction in growth of all populations of $P$. antidotale. However, leaf wilting in populations of $P$. antidotale that from Cholistan desert was observed after four weeks. Detailed chlorophyll fluorescence analysis suggested that drought tolerance was mainly due to maintenance of leaf water content and regulation of electron transport and protection of PSII from drought induced oxidative stress. Photoinhibition of PSII was lesser in populations that from Cholistan desert. Chlorophyll $a$ fluorescence is non-invasive technique which can be used for measurement of stress tolerance level and screening purpose.

\section{Acknowledgements}

The work presented in this manuscript is a part of $\mathrm{PhD}$ research work conducted by Muhammad Javed. 


\section{References}

AKRAM, N.A., SHAHBAZ, M. and ASHRAF, M., 2008. Nutrient acquisition in differentially adapted populations of Cynodon dactylon (L.) Pers. and Cenchrus ciliaris L. under drought stress. Pakistan Journal of Botany, vol. 40, no. 4, pp. 1433-1440.

ALAM, S.M., 1994. Nutrient uptake by plants under stress conditions. In: M. PESSRAKLI, ed. Handbook of plant and crop stress. New York: Marcel Dekker, vol. 1, pp. 227-246.

AL-KHATIB, M., MCNEILLY, T. and COLLINS, J., 1992. The potential of selection and breeding for improved salt tolerance in lucerne (Medicago sativa L.). Euphytica, vol. 65, no. 1, pp. 43-51. http:// dx.doi.org/10.1007/BF00022198.

ALLAKHVERDIEV, S.I., HAYASHI, H., NISHIYAMA, Y., IVANOV, A.G., ALIEV, J.A., KLIMOV, V.V., MURATA, N. and CARPENTIER, R., 2003. Glycinebetaine protects the D1/D2/Cytb559 complex of photosystem II against photo-induced and heat-induced inactivation. Journal of Plant Physiology, vol. 160, no. 1, pp. 41-49. http://dx.doi.org/10.1078/0176-1617-00845. PMid:12685044.

ALLEN, S.E., GRIMSHAW, H.M. and ROWLAND, A.P., 1986. Chemical analysis. In: P.D. MOORE and S.B. CHAPMAN, eds. Methods in plant ecology. Oxford: Blackwell Scientific Publication, pp. 258-344.

APEL, K. and HIRT, H., 2004. Reactive oxygen species: metabolism, oxidative stress and signal transduction. Annual Review of Plant Biology, vol. 55, no. 1, pp. 373-399. http://dx.doi.org/10.1146/ annurev.arplant.55.031903.141701. PMid:15377225.

ARNON, D.I., 1949. Copper enzymes in isolated chloroplasts polyphenoloxidase in Beta vulgaris. Plant Physiology, vol. 24, no. 1, pp. 1-15. http://dx.doi.org/10.1104/pp.24.1.1. PMid:16654194.

ARSHAD, M., HASSAN, A., ASHRAF, M.Y., NOUREEN, S. and MOAZZAM, M., 2008. Edaphic factors and distribution of vegetation in the Cholistan desert, Pakistan. Pakistan Journal of Botany, vol. 40 , no. 5, pp. 1923-1931.

ASHRAF, M. and HARRIS, P.J.C., 2013. Photosynthesis under stressful environments: an overview. Photosynthetica, vol. 51, no. 2, pp. 163-190. http://dx.doi.org/10.1007/s11099-013-0021-6.

ASHRAF, M. and MCNEILLY, T., 1990. Response of four Brassica species to $\mathrm{NaCl}$. Environmental and Experimental Botany, vol. 30, no. 4, pp. 475-487. http://dx.doi.org/10.1016/0098-8472(90)90028-3.

ASHRAF, M. and YASMIN, N., 1995. Responses of four arid zone grass species from varying habitats to drought stress. Biologia Plantarum, vol. 37, no. 4, pp. 567-575. http://dx.doi.org/10.1007/ BF02908840.

ASHRAF, M., 2009. Biotechnological approach of improving plant salt tolerance using antioxidants as markers. Biotechnology Advances, vol. 27, no. 1, pp. 84-93. http://dx.doi.org/10.1016/j. biotechadv.2008.09.003. PMid:18950697.

ASHRAF, M., MCNEILLY, T. and BRADSHAW, A.D., 1986. Tolerance of Holcus lanatus and Agrostis stolonifera to sodium chloride in soil solution and saline spray. Plant and Soil, vol. 96, no. 1, pp. 77-84. http://dx.doi.org/10.1007/BF02374997.

ASHRAF, M., NAWAZISH, S. and ATHAR, H., 2007. Are chlorophyll fluorescence and photosynthetic capacity potential physiological determinants of drought tolerance in maize (Zea mays L.). Pakistan Journal of Botany, vol. 39, no. 4, pp. 1123-1131.

BALIGAR, V., FAGERIA, N. and HE, Z., 2001. Nutrient use efficiency in plants. Communications in Soil Science and Plant Analysis, vol. 32 no. 7-8, pp. 921-950. http://dx.doi.org/10.1081/CSS-100104098.

BENNINGTON, C.C. and MCGRAW, J.B., 1995. Natural selection and ecotypic differentiation in Impatiens pallida. Ecological Monographs, vol. 65, no. 3, pp. 303-324. http://dx.doi. org/10.2307/2937062.
BLUM, A., 2005. Drought resistance, water-use efficiency, and yield potential-are they compatible, dissonant, or mutually exclusive? Australian Journal of Agricultural Research, vol. 56, no. 11, pp. 1159. http://dx.doi.org/10.1071/AR05069.

BLUM, A., 2017. Osmotic adjustment is a prime drought stress adaptive engine in support of plant production. Plant, Cell $\mathcal{E}$ Environment, vol. 40, no. 1, pp. 4-10. http://dx.doi.org/10.1111/ pce.12800. PMid:27417527.

BOYER, J.S., 1982. Plant productivity and environment. Science, vol. 218 , no. 4571 , pp. 443-448. http://dx.doi.org/10.1126/ science.218.4571.443. PMid:17808529.

BOYER, J.S., JAMES, R.A., MUNNS, R., CONDON, T.A.G. and PASSIOURA, J.B., 2008. Osmotic adjustment leads to anomalously low estimates of relative water content in wheat and barley. Functional Plant Biology, vol. 35, no. 11, pp. 1172-1182. http:// dx.doi.org/10.1071/FP08157. PMid:32688864.

BRADFORD, M.M., 1976. A rapid and sensitive method for the quantitation of microgram quantities of protein utilizing the principle of protein-dye binding. Analytical Biochemistry, vol. 72, no. 1-2, pp. 248-254. http://dx.doi.org/10.1016/00032697(76)90527-3. PMid:942051.

BUSSOTTI, F., 2004. Assessment of stress conditions in Quercus ilex L. leaves by O-J-I-P chlorophyll $a$ fluorescence analysis. Plant Biosystems, vol. 138, no. 2, pp. 101-109. http://dx.doi.org/10.1 080/11263500412331283708.

BUSSOTTI, F., GEROSA, G., DIGRADO, A. and POLLASTRINI, M., 2020. Selection of chlorophyll fluorescence parameters as indicators of photosynthetic efficiency in large scale plant ecological studies. Ecological Indicators, vol. 108, pp. 105686. http://dx.doi.org/10.1016/j.ecolind.2019.105686.

CAKMAK, I. and HORST, W.J., 1991. Effect of aluminium on lipid peroxidation, superoxide dismutase, catalase, and peroxidase activities in root tips of soybean (Glycine max). Physiologia Plantarum, vol. 83, no. 3, pp. 463-468. http://dx.doi. org/10.1111/j.1399-3054.1991.tb00121.x.

CEPPI, M.G., OUKARROUM, A., CICEK, N., STRASSER, R.J. and SCHANSKER, G., 2012. The IP amplitude of the fluorescence rise OJIP is sensitive to changes in the photosystem I content of leaves: A study on plants exposed to magnesium and sulfate deficiencies, drought stress and salt stress. Physiologia Plantarum, vol. 144, no. 3, pp. 277-288. http://dx.doi.org/10.1111/j.13993054.2011.01549.x. PMid:22121914.

DU, H., WANG, N., CUI, F., LI, X., XIAO, J. and XIONG, L., 2010. Characterization of a $\beta$-carotene hydroxylase gene DSM2 conferring drought and oxidative stress resistance by increasing xanthophylls and abscisic acid synthesis in rice. Plant Physiology, vol. 154, no. 3, pp. 1304-1318. http://dx.doi.org/10.1104/ pp.110.163741. PMid:20852032.

DUDLEY, S.A., 1996a. Differing selection on plant physiological traits in response to environmental water availability: A test of adaptive hypotheses. Evolution; International Journal of Organic Evolution, vol. 50, no. 1, pp. 92-102. http://dx.doi. org/10.1111/j.1558-5646.1996.tb04475.x. PMid:28568873.

DUDLEY, S.A., 1996b. The response to differing selection on plant physiological traits: evidence for local adaptation. Evolution; International Journal of Organic Evolution, vol. 50, no. 1, pp. 103-110. http://dx.doi.org/10.1111/j.1558-5646.1996.tb04476.x. PMid:28568863.

FOYER, C.H., 2018. Reactive oxygen species, oxidative signaling and the regulation of photosynthesis. Environmental and Experimental Botany, vol. 154, pp. 134-142. http://dx.doi.org/10.1016/j. envexpbot.2018.05.003. PMid:30283160. 
GARG, B.K., 2003. Nutrient uptake and management under drought: nutrient-moisture interaction. Current Agriculture, vol. 27, pp. 1-8.

GOLTSEV, V., ZAHARIEVA, I., CHERNEV, P., KOUZMANOVA, M., KALAJI, H.M., YORDANOV, I., KRASTEVA, V., ALEXANDROV, V., STEFANOV, D., ALLAKHVERDIEV, S.I. and STRASSER, R.J., 2012. Droughtinduced modifications of photosynthetic electron transport in intact leaves: analysis and use of neural networks as a tool for a rapid non-invasive estimation. Biochimica et Biophysica Acta (BBA) - Bioenergetics, vol. 1817, no. 8, pp. 1490-1498.

GOLTSEV, V.N., KALAJI, H.M., PAUNOV, M., BĄBA, W., HORACZEK, T., MOJSKI, J., KOCIEL, H. and ALLAKHVERDIEV, S.I., 2016. Variable chlorophyll fluorescence and its use for assessing physiological condition of plant photosynthetic apparatus. Russian Journal of Plant Physiology: a Comprehensive Russian Journal on Modern Phytophysiology, vol. 63, no. 6, pp. 869-893. http://dx.doi. org/10.1134/S1021443716050058.

GOSSETT, D.R., MILLHOLLON, E.P. and LUCAS, M., 1994. Antioxidant response to $\mathrm{NaCl}$ stress in salt-tolerant and salt-sensitive cultivars of cotton. Crop Science, vol. 34, no. 3, pp. 706-714. http:// dx.doi.org/10.2135/cropsci1994.0011183X003400030020x.

GUAN, X.K., SONG, L., WANG, T.C., TURNER, N. and LI, F.M., 2015. Effect of drought on the gas exchange, chlorophyll fluorescence and yield of six different-era spring wheat cultivars. Journal Agronomy \& Crop Science, vol. 201, no. 4, pp. 253-266. http:// dx.doi.org/10.1111/jac.12103.

GUHA, A. and REDDY, A.R., 2014. Leaf gas exchange, water relations and photosystem-II functionality depict anisohydric behavior of drought-stressed mulberry (Morus indica, cv. V1) in the hot semi-arid steppe agroclimate of Southern India. FloraMorphology, Distribution. Functional Ecology of Plants, vol. 209, no. 2, pp. 142-152. http://dx.doi.org/10.1016/j.flora.2013.12.007.

GUHA, A., SENGUPTA, D. and REDDY, A.R., 2013. Polyphasic chlorophyll $a$ fluorescence kinetics and leaf protein analyses to track dynamics of photosynthetic performance in mulberry during progressive drought. Journal of Photochemistry and Photobiology. B, Biology, vol. 119, pp. 71-83. http://dx.doi. org/10.1016/j.jphotobiol.2012.12.006. PMid:23357190.

GUILIONI, L., JONES, H., LEINONEN, I. and LHOMME, J.-P., 2008. On the relationships between stomatal resistance and leaf temperatures in thermography. Agricultural and Forest Meteorology, vol. 148, no. 11, pp. 1908-1912. http://dx.doi. org/10.1016/j.agrformet.2008.07.009.

GUNES, A., CICEK, N., INAL, A., ALPASLAN, M., ERASLAN, F., GUNERI, E. and GUZELORDU, T., 2006. Genotypic response of chickpea (Cicer arietinum $\mathrm{L}$.) cultivars to drought stress implemented at pre-and post-anthesis stages and its relations with nutrient uptake and efficiency. Plant, Soil and Environment, vol. 52, no. 8, pp. 368-376. http://dx.doi.org/10.17221/3454-PSE.

HAMEED, M., CHAUDHRY, A.A., MAAN, M.A. and GILL, A.H., 2002. Diversity of plant species in Lal Suhanra National Park, Bahawalpur, Pakistan. The Journal of Biological Sciences, vol. 2 , no. 4, pp. 267-274. http://dx.doi.org/10.3923/jbs.2002.267.274.

HELALY, M.N., EL-HOSEINY, H., EL-SHEERY, N.I., RASTOGI, A. and KALAJI, H.M., 2017. Regulation and physiological role of silicon in alleviating drought stress of mango. Plant Physiology and Biochemistry, vol. 118, pp. 31-44. http://dx.doi.org/10.1016/j. plaphy.2017.05.021. PMid:28603082.

HESCHEL, M.S., DONOHUE, K., HAUSMANN, N. and SCHMITT, J., 2002. Population differentiation and natural selection for water-use efficiency in Impatiens capensis (Balsaminaceae). International Journal of Plant Sciences, vol. 163, no. 6, pp. 907912. http://dx.doi.org/10.1086/342519.
HUSEYNOVA, I.M, SULEYMANOV, S.Y., RUSTAMOVA, S.M. and ALIYEV, J.A., 2009. Drought-induced changes in photosynthetic membranes of two wheat (Triticum aestivum L.) cultivars. Biochemistry (Moscow), vol. 74, no. 8, pp. 903-909. http://dx.doi. org/10.1134/S0006297909080124. PMid:19817691.

JALEEL, C.A., MANIVANNAN, P., WAHID, A., FAROOQ, M., ALJUBURI, H.J., SOMASUNDARAM, R. and PANNEERSELVAM, R., 2009. Drought stress in plants: a review on morphological characteristics and pigments composition. International Journal of Agriculture and Biology, vol. 11, no. 1, pp. 100-105.

KHAN, A., MUJTABA, S. and KHANZADA, B., 1999. Response of growth, water relation and solute accumulation in wheat genotypes under water deficit. Pakistan Journal of Botany, vol. 31, pp. 461-468.

KIRST, H., GABILLY, S.T., NIYOGI, K.K., LEMAUX, P.G. and MELIS, A., 2017. Photosynthetic antenna engineering to improve crop yields. Planta, vol. 245, no. 5, pp. 1009-1020. http://dx.doi. org/10.1007/s00425-017-2659-y. PMid:28188423.

KRIEGER-LISZKAY, A., 2005. Singlet oxygen production in photosynthesis. Journal of Experimental Botany, vol. 56, no. 411, pp. 337-346. http://dx.doi.org/10.1093/jxb/erh237. PMid:15310815.

LAWLOR, D.W. and CORNIC, G., 2002. Photosynthetic carbon assimilation and associated metabolism in relation to water deficits in higher plants. Plant, Cell E Environment, vol. 25, no. 2, pp. 275-294. http://dx.doi.org/10.1046/j.00168025.2001.00814.x. PMid:11841670.

LAWLOR, D.W., 2002. Carbon and nitrogen assimilation in relation to yield: mechanisms are the key to understanding production systems. Journal of Experimental Botany, vol. 53, no. 370, pp. 773-787. http://dx.doi.org/10.1093/jexbot/53.370.773. PMid:11912221.

LOTFI, R., KALAJI, H.M., VALIZADEH, G.R., BEHROZYAR, E., HEMATI, A., GHARAVI-KOCHEBAGH, P. and GHASSEMI, A., 2018. Effects of humic acid on photosynthetic efficiency of rapeseed plants growing under different watering conditions. Photosynthetica, vol. 56, no. 3, pp. 962-970. http://dx.doi.org/10.1007/s11099017-0745-9.

MARSCHNER, H., 1995. Mineral nutrition of higher plants. New York: Academic Press.

MURCHIE, E.H., 2017. Safety conscious or living dangerously: what is the 'right' level of plant photoprotection for fitness and productivity? Plant, Cell \& Environment, vol. 40, no. 8, pp. 1239-1242. http://dx.doi.org/10.1111/pce.12965. PMid:28382767.

NAZ, N., HAMEED, M., ASHRAF, M., AHMAD, R. and ARSHAD, M., 2009. Eco-morphic variation for salt tolerance in some grasses from Cholistan desert. Pakistan. Pakistan Journal of Botany, vol. 41, no. 4, pp. 1707-1714.

NOBLE, C., HALLORAN, G. and WEST, D., 1984. Identification and selection for salt tolerance in lucerne (Medicago sativa L.). Australian Journal of Agricultural Research, vol. 35, no. 2, pp. 239-252. http://dx.doi.org/10.1071/AR9840239.

PAN, Y., WU, L.J. and YU, Z.L., 2006. Effect of salt and drought stress on antioxidant enzymes activities and SOD isoenzymes of liquorice (Glycyrrhiza uralensis Fisch). Plant Growth Regulation, vol. 49, no. 2, pp. 157-165. http://dx.doi.org/10.1007/s10725-006-9101-y.

RAPACZ, M., WÓJCIK-JAGŁA, M., FIUST, A., KALAJI, H.M. and KOŚCIELNIAK, J., 2019. Genome-wide associations of chlorophyll fluorescence OJIP transient parameters connected with soil drought response in barley. Frontiers in Plant Science, vol. 10, pp. 78. http://dx.doi.org/10.3389/fpls.2019.00078. PMid:30828338.

REDILLAS, M.C.F.R., STRASSER, R.J., JEONG, J.S., KIM, Y.S. and KIM, J.-K., 2011. The use of JIP test to evaluate drought-tolerance of 
transgenic rice overexpressing OsNAC10. Plant Biotechnology Reports, vol. 5, no. 2, pp. 169-175. http://dx.doi.org/10.1007/ s11816-011-0170-7.

RUBAN, A.V., 2016. Non photochemical chlorophyll fluorescence quenching: mechanism and effectiveness in protecting plants from photodamage. Plant Physiology, vol. 170, no. 4, pp. 19031916. http://dx.doi.org/10.1104/pp.15.01935. PMid:26864015.

SAMARAH, N., MULLEN, R. and CIANZIO, S., 2004. Size distribution and mineral nutrients of soybean seeds in response to drought stress. Journal of Plant Nutrition, vol. 27, no. 5, pp. 815-835. http://dx.doi.org/10.1081/PLN-120030673.

SHAHBAZ, M., IQBAL, M. and ASHRAF, M., 2012. Response of differently adapted populations of blue panic grass (Panicum antidotale Retz.) to water deficit conditions. Journal of Applied Botany and Food Quality, vol. 84, no. 2, pp. 134-141.

SILVA, E.N., FERREIRA-SILVA, S.L., VIÉGAS, R.A. and SILVEIRA, J.A.G., 2010. The role of organic and inorganic solutes in the osmotic adjustment of drought-stressed Jatropha curcas plants. Environmental and Experimental Botany, vol. 69, no. 3, pp. 279-285. http://dx.doi.org/10.1016/j.envexpbot.2010.05.001.

SNEDECOR, G.W. and COCHRAN, W.G., 1989. Statistical methods. 8th ed. Ames: Iowa State University Press.

STIRBET, A. and GOVINDJEE, 2011. On the relation between the Kautsky effect (chlorophyll $a$ fluorescence induction) and Photosystem II: basics and applications of the OJIP fluorescence transient. Journal of Photochemistry and Photobiology. B, Biology, vol. 104, no. 1-2, pp. 236-257. http://dx.doi.org/10.1016/j. jphotobiol.2010.12.010. PMid:21295993.

STRASSER, R., TSIMILLI-MICHAEL, M. and SRIVASTAVA, A., 2004. Analysis of the chlorophyll a fluorescence transient. In: G.C. PAPAGEORGIOU and GOVINDJEE, eds. Chlorophyll a fluorescence. Netherlands: Springer, vol. 19, pp. 321-362.

STRASSER, R., TSIMILLI-MICHAEL, M., DANGRE, D. and RAI, M., 2007. Biophysical phenomics reveals functional building blocks of plants systems biology: a case study for the evaluation of the impact of mycorrhization with Piriformospora indica. In: A. VARMA and R. OELMÜLLER, eds. Advanced techniques in soil microbiology. Heidelberg: Springer, vol. 11, pp. 319-341.

STRASSER, R.J., SRIVASTAVA, A. and TSIMILLI-MICHAEL, M., 2000. The fluorescence transient as a tool to characterize and screen photosynthetic samples. In: M. YUNUS, U. PATHRE, and P. MOHANTY, eds. Probing photosynthesis: mechanism, regulation E adaptation. Boca Raton: CRC Press, pp. 445-483.

TAIZ, L., ZEIGER, E., MOLLER, I.S. and MURPHY, A., editors 2015. Plant physiology and development. Massachusetts, USA: Sinauer Associates Inc.
TANGUILIG, V., YAMBAO, E., O'TOOLE, J. and DE DATTA, S., 1987. Water stress effects on leaf elongation, leaf water potential, transpiration, and nutrient uptake of rice, maize, and soybean. Plant and Soil, vol. 103, no. 2, pp. 155-168. http://dx.doi. org/10.1007/BF02370385.

VAN SLYKE, D.D., MACFADYEN, D.A. and HAMILTON, P.B., 1943. The gasometric determination of amino acids in urine by the ninhydrin-carbon dioxide method. The Journal of Biological Chemistry, vol. 150, no. 1, pp. 251-258. http://dx.doi.org/10.1016/ S0021-9258(18)51269-2.

VELIKOVA, V., YORDANOV, I. and EDREVA, A., 2000. Oxidative stress and some antioxidant systems in acid rain-treated bean plants: protective role of exogenous polyamines. Plant Science, vol. 151, no. 1, pp. 59-66. http://dx.doi.org/10.1016/ S0168-9452(99)00197-1.

WANG, W., VINOCUR, B. and ALTMAN, A., 2003. Plant responses to drought, salinity and extreme temperatures: towards genetic engineering for stress tolerance. Planta, vol. 218, no. 1, pp. 1-14. http://dx.doi.org/10.1007/s00425-003-1105-5. PMid:14513379.

WANG, Z., ZHENG, P., MENG, J. and XI, Z., 2015. Effect of exogenous 24-epibrassinolide on chlorophyll fluorescence, leaf surface morphology and cellular ultrastructure of grape seedlings (Vitis vinifera L.) under water stress. Acta Physiologiae Plantarum, vol. 37, no. 1, pp. 1-12. https://doi.org/10.1007/s11738-014-1729-z.

WANG, Z.X., CHEN, L., AI, J., QIN, H.Y., LIU, Y.X., XU, P.L., JIAO, Z.Q., ZHAO, Y. and ZHANG, Q.T., 2012. Photosynthesis and activity of photosystem II in response to drought stress in amur grape (Vitis amurensis Rupr.). Photosynthetica, vol. 50, no. 2, pp. 189196. http://dx.doi.org/10.1007/s11099-012-0023-9.

ZIVCAK, M., BRESTIC, M., BALATOVA, Z., DREVENAKOVA, P., OLSOVSKA, K., KALAJI, H., YANG, X. and ALLAKHVERDIEV, S., 2013. Photosynthetic electron transport and specific photoprotective responses in wheat leaves under drought stress. Photosynthesis Research, vol. 117, no. 1-3, pp. 529-546. http://dx.doi.org/10.1007/ s11120-013-9885-3. PMid:23860828.

ZIVCAK, M., KALAJI, H.M., SHAO, H.-B., OLSOVSKA, K. and BRESTIC, M., 2014. Photosynthetic proton and electron transport in wheat leaves under prolonged moderate drought stress. Journal of Photochemistry and Photobiology. B, Biology, vol. 137, no. 0, pp. 107-115. http://dx.doi.org/10.1016/j.jphotobiol.2014.01.007. PMid:24508481.

ZLATEV, Z., LIDON, F., RAMALHO, J. and YORDANOV, I., 2006. Comparison of resistance to drought of three bean cultivars. Biologia Plantarum, vol. 50, no. 3, pp. 389-394. http://dx.doi. org/10.1007/s10535-006-0054-9. 


\section{Abbreviations}

\begin{tabular}{|c|c|}
\hline Symbols/Items & Descriptions \\
\hline SFW & Shoot fresh weight \\
\hline SDW & Shoot dry weight \\
\hline RFW & Root fresh weight \\
\hline RFW & Root dry weight \\
\hline Chl $a$ & Chloropyll $a$ \\
\hline Chl $b$ & Chlorophyll $b$ \\
\hline Chl $a /$ Chl $b$ & Chloropyll $a /$ Chlorophyll $b$ ratio \\
\hline Total Chl & Total chlorophyll \\
\hline $\mathrm{Car} / \mathrm{Chl}$ & Carotenoids/Chlorophyll ratio \\
\hline RWC & Relative water content \\
\hline $\mathrm{OP}$ & Osmotic potential \\
\hline TSP & Total soluble proteins \\
\hline TFAA & Total free amino acids \\
\hline $\mathrm{H}_{2} \mathrm{O}_{2}$ & Hydrogen peroxide \\
\hline MDA & Malondialdehyde \\
\hline $\mathrm{K}^{+}$ & Potassium ion \\
\hline PSI & Photosystem I \\
\hline PSII & Photosystem II \\
\hline LHC & Light harvest complex \\
\hline RC & Reaction center \\
\hline $\mathrm{Q}_{\mathrm{A}}$ & Quinone A (Primary quinone acceptor of PSII) \\
\hline $\mathrm{Q}_{\mathrm{B}}$ & Quinone B (Secondary quinone acceptor of PSII) \\
\hline K step & Stability of oxygen evolving complex \\
\hline J step & Energetic connectivity of PSII core-complex with antennae \\
\hline I step & Re-reduction of PQ pool by PSI activity \\
\hline Fo & $\begin{array}{l}\text { Minimum fluorescence }(50 \mu \mathrm{s}) \text { of OJIP, when all reaction } \\
\text { centers of PSII are assumed to be open. }\end{array}$ \\
\hline Fm & $\begin{array}{l}\text { Maximum fluorescence at the peak of OJIP, when all reaction } \\
\text { centers of PSII are assumed to be close. }\end{array}$ \\
\hline $\mathrm{Fj}$ & Fluorescence at J step (2 ms) of OJIP \\
\hline $\mathrm{Fi}$ & Fluorescence at I step (30 ms) of OJIP \\
\hline $\mathrm{Fv}$ & Variable chlorophyll fluorescence \\
\hline $\mathrm{Vj}$ & Variable chlorophyll fluorescence at J step \\
\hline Vi & Variable chlorophyll fluorescence at I step \\
\hline Fm/Fo & Fm/Fo ratio \\
\hline Fv/Fo & $\begin{array}{l}\text { Fv/Fo ratio (a value that is proportional to the activity of the } \\
\text { water-splitting complex on the donor side of the PSII) }\end{array}$ \\
\hline $\mathrm{Fv} / \mathrm{Fm}$ & $\begin{array}{l}\mathrm{Fv} / \mathrm{Fm} \text { ratio (a value that is related to the maximum quantum } \\
\text { yield of PSII) }\end{array}$ \\
\hline Mo & $\begin{array}{l}\text { Rate of closure of PSII (Approximate value of the initial slope } \\
\text { of relative variable chlorophyll fluorescence curve) }\end{array}$ \\
\hline Area & $\begin{array}{l}\text { Area above chlorophyll fluorescence curve between Fo and Fm } \\
\text { (representing size of plastoquinone pool }\end{array}$ \\
\hline Fix Area & $\begin{array}{l}\text { Fix area above chlorophyll fluorescence curve between Fo and } \\
\text { Fm (representing size of plastoquinone pool) }\end{array}$ \\
\hline $\mathrm{N}$ & $\begin{array}{l}\text { Number of } Q_{A} \text { redox turnovers until Fm is reached (the } \\
\text { number indicating how many times } Q A \text { is reduced while } \\
\text { fluorescence reaches its maximal value) }\end{array}$ \\
\hline $\mathrm{PI}_{\mathrm{ABS}}$ & $\begin{array}{l}\text { Performance index for energy conservation from photon } \\
\text { absorbed by PSII antenna to reduction of } Q_{B}\end{array}$ \\
\hline $\mathrm{ABS} / \mathrm{RC}$ & Absorbed energy flux per PSII reaction center \\
\hline TRo/RC & Trapped energy flux per PSII reaction center \\
\hline $\mathrm{ETo} / \mathrm{RC}$ & Electron transport flux per PSII reaction center \\
\hline $\mathrm{DIo} / \mathrm{RC}$ & Dissipated energy per PSII reaction center \\
\hline
\end{tabular}

